\title{
Moralne korelaty nastawień wobec pracy kandydatów na nauczycieli-wychowawców
}

\author{
The Moral Correlates \\ of the Approach Towards the Work \\ of Teachers-Tutors Candidates
}

\begin{abstract}
ABSTRAKT
Celem artykułu jest empiryczna charakterystyka nastawień wobec pracy przyszłych nauczycieli-wychowawców oraz moralnych korelatów tych nastawień. Badania przeprowadzono w okresie od grudnia 2017 do lutego 2018 roku w grupie 227 studentów pedagogiki Uniwersytetu Szczecińskiego. Sformułowano następujący problem badawczy: Czy istnieje zwiqzek pomiędzy nastawieniem wobec pracy a wartościami i uczuciami moralnymi studentów pedagogiki? Przyięto hipotezę, że zachodzi istotny statystycznie zwiqzek pomiędzy nastawieniem wobec pracy a wartościami i uczuciami moralnymi badanych osób. Obliczenia statystyczne wykonane zostały w modelu korelacyinym.

Badani studenci cechowali się głównie nastawieniem do pracy jako sposobu na samorealizację, zaś w najmniejszym stopniu - jako oznaki prestiżu społecznego i konieczności. Charakteryzowali się raczej wysokim wartościowaniem wiedzy i poznania oraz pomocy innym ludziom, często też dążeniem do piękna, harmonii i tworzenia. Ponadto, przeciętnym
\end{abstract}

SLOWA KLUCZOWE nastawienia wobec pracy, wartości, uczucia moralne, studenci pedagogiki, chaos aksjonormatywny

\section{KEYWORDS}

approach towards work, values, moral feelings, pedagogics students, axionormative chaos

SPI Vol. 21, 2018/4

ISSN 2450-5358

e-ISSN 2450-5366 DOI: 10.12775/SPI.2018.4.007

Nadestano: 29.09.2018 Zaakceptowano: 10.12.2018

Raporty z badań 
wartościowaniem dóbr konsumpcyinych i wygód życia oraz raczej obniżonym dażeniem do dominacji i posiadania władzy nad innymi ludźmi. W pomiarze uczuć moralnych dominowały pozyływne wartości zwiqzane z realizowaniem norm moralnych.

Analiza korelacji wykazała szereg powiqzań pomiędzy badanymi cechami. Najkorzystniejszymi wartościami i uczuciami moralnymi cechowały się osoby, kłóre w większym stopniu postrzegały pracę jako narzędzie samorealizacji. Pozytywny obraz badanych zmiennych wykazywały też osoby nastawione do pracy jak do powinności społecznej, miejsca realizacji potrzeb tożsamości i identyfikacji oraz nawiq̨zywania kontaktów społecznych. Natomiast traktowanie pracy jako ekonomicznej konieczności czy oznaki społecznego prestiżu powiqzane było z mniej moralnym nastawieniem do realizacji i przekraczania norm oraz większym nasileniem niekonstruktywnych potrzeb doznawania uciech doczesnych i dominacji nad innymi ludźmi.

\section{ABSTRACT}

The main goal of the article is presentation of the empirical characteristics of future teacher-tutor and the moral correlates of these approaches. The research was conducted from December 2017 to February 2018 amongst a group of 227 students of the Pedagogical Faculty of Szczecin University. The following research thesis was constructed: is there a relation between the approach towards work and moral values as well as moral feelings of Pedagogy students? The hypothesis was adopted that there is statistically significant relation between the approach towards work and moral values and moral feelings of the examined participants. The statistical calculations were conducted in correlation model.

The examined students' approach towards work mainly featured self-fulfillment, although less as an indication of social prestige and necessity. They were characterized with rather high knowledge and cognition values recognition, as well as helpfulness towards other people, often with beauty, harmony and creation desire. Moreover, they valued consuming goods, life comfort only as average and they had a lower need to dominate and possess power over other people. In moral feelings measurement, the positive values connected with the realization of moral norms dominated.

The correlation analysis revealed a range of connections between the examined features. The persons who presented the most beneficial moral values and moral feelings were those who perceived their work as a tool for self-fulfillment. The positive layout of the examined variables presented 
persons who treated their work as a social obligation, a place to fulfill the self-identity needs and social relations. On the other hand, treating their job as an economic necessity or a sign of social prestige, related to a less moral approach to the realization of duties and schemata crossing, as well as a greater impact of the deconstructive need to use temporal pleasures and a dominance over other people.

\section{Wprowadzenie}

Ogłoszono już koniec Boga i koniec człowieka. Nic się nie sprawdziło. Nadal trzeba sobie radzić, i to w czasach chaosu aksjonormatywnego. Chaos to stan pozbawiony ładu; chaos aksjonormatywny dotyczy bezładu wartości i norm. To, co dzieje się codziennie, przestało być oczywiste. Negowane jest prawo naturalne i podważane są normy społeczno-kulturowe, a nienormalność wciskana jest w ramy norm. Można „pogubić się” w rozróżnianiu prawdy i fałszu, spraw ważnych i błahych, wymiarów trwałych i ulotnych. Permanentna zmiana ciągle nabiera tempa, poszerzając zakres człowieczego nienasycenia i tworzenia, ale też lęku i dezorientacji aksjonormatywnej. Sam proces tego rozpędu nie jest tak straszny, jak to, że współczesny człowiek zatraca poczucie celu i sensu tego przyspieszenia: dokąd zmierza i dlaczego? To przecież podstawowe pytanie egzystencjalne, z którego wynika sens życia. W biegu człowiek nie ma czasu na refleksję. Rezygnuje $\mathrm{z}$ dalekiej perspektywy w działaniach, preferując krótkotrwałość we wszystkim, również w związkach międzyludzkich. Tymczasem, poczucie bezpieczeństwa egzystencjalnego jest podstawową ludzką potrzebą, wymagającą równowagi między tym, co szybkie i zmienne, a tym, co stałe i powtarzalne ${ }^{1}$. Polski filozof, historyk nauki i kultury, pedagog Bogdan Suchodolski już w ubiegłym wieku zauważył:

Żyjemy w trudnych czasach. W życiu wewnętrznym człowieka, podobnie jak w życiu zbiorowym, wzrasta chaos. [...] Jeśli jednak nie mamy zwątpić w człowieka i w sens życia w ogóle, musimy szukać dróg wyjścia, zarówno z chaosu, jak i z zaślepień².

1 J.M. Łukasik, Doświadczanie życia codziennego. Narracje nauczycielek na przetomie życia, Kraków 2013, s. 281.

2 B. Suchodolski, Skąd i dokąd idziemy, Warszawa 1999, s. 5. 
Droga wyjścia z chaosu aksjonormatywnego w zmieniającej się rzeczywistości społecznej prowadzi przez wartości. Jan Paweł II w swej mądrości zauważył, że człowiek, żyjąc poza tym, co istotne, daleko od siebie i Boga, doświadcza pustki wewnętrznej. ${ }^{3}$ W pustce, próżni czy zawieszeniu nie ma możliwości znalezienia sensu życia, pracy ani wypoczynku. Pustkę trzeba wypełnić. Dla poczucia sensu wydarzenia, zadania, zachowania, konieczne jest, by miały one wartość. Optymalne doświadczenie człowieka jest przeżywaniem przez niego głębokiego sensu działania. Sensowność oznacza „nadawanie znaczenia czynnościom tak, by koncentrowały one uwage (wysiłki i starania) oraz angażowały, dając poczucie radości jej wykonywania" ${ }^{4} \mathrm{Z}$ kolei nadawanie znaczenia polega na uporządkowaniu świadomości poprzez „scalenie” wykonywanych czynności, podporządkowując je swojej n ajw yżs zej wartości ${ }^{5}$. Jeśli znaczenie posiada każda wykonywana czynność tak w teraźniejszości, jak i z perspektywy przeszłości i przyszłości, to sens posiada całe działanie, a integracja takich działań w kolejnych wymiarach codziennego funkcjonowania skutkuje sensownością życia ${ }^{6}$. Sensowności można szukać np. w formalnoprawnych przepisach, normach społecznych i religijnych - jest to tzw. poczucie sensu w szerokim, społecznym wymiarze. Optymalne doświadczenie wymaga jednak p r z e życia sensowności, czyli odniesienia wiedzy do sfery emocjonalno-wolicjonalnej. Istotne jest poczucie sensu indywidualnego, które nie wyklucza sensu w szerszym, społecznym wymiarze. Sensu nie należy więc jedynie szukać, lecz sens należy także nadawać?: nadawać wartość podejmowanym działaniom.

Stałe poczucie sensu jest warunkiem życiowej szczęśliwości ${ }^{8}$. Bez względu na jakość zmian w rzeczywistości społecznej, człowiek

3 K. Wojtyła [Jan Paweł II], "Jestem bardzo w rękach Bożych". Notatki osobiste 1962-2003, Kraków 2014, s. 427.

4 I. Jazukiewicz, Pedeutologiczna teoria cnoty, Szczecin 2012, s. 202.

5 Por. tamże, s. 202.

6 Optymalnego doświadczenia człowieka dotyczy teoria flow amerykańskiego psychologa M. Csikszentmihalyiego w książce pt. Przeptyw. Psychologia optymalnego doświadczenia, przeł. M. Wajda-Kacmajor, Taszów 2005.

7 Por. J. Walkiewicz, Petna moc możliwości, Gliwice 2015, s. 95; K. Popper, W poszukiwaniu lepszego świata, przeł. A. Malinowski, Warszawa 1997, s. 162.

8 Potwierdzają to badania M. Csíkszentmihályi przedstawione w książce pt. Przeptyw. Psychologia optymalnego doświadczenia, dz. cyt. 
pragnie być szczęśliwy, choć nie każda zmiana temu sprzyja. Wiadomo z badań, że tym, co wyróżnia osoby szczęśliwe spośród społeczeństwa „nie są ani komfortowe warunki życia i stan zdrowia, ani cechy demograficzne, takie jak wiek, płeć czy wykształcenie, ani też zrządzenia losu, choćby najbardziej przełomowe i pociągające za sobą długotrwałe konsekwencje (np. wysoka wygrana w grze liczbowej)" Poszukiwane są czynniki wpływające na poczucie szczęścia współczesnego człowieka. Według znawcy nauki o szczęściu, psychologa Janusza Czapińskiego, na poczucie szczęścia może wpływać system wartości ${ }^{10}$. Decyduje on o sposobie spostrzegania świata, innych i siebie; o nastawieniu do tego, co nas spotyka; o odnalezieniu (bądź nie) sensu tego, co doświadczamy. Według filozofów i współczesnych psychologów

[...] to nie rzeczy same w sobie martwią lub cieszą człowieka, lecz to, jak je spostrzega. [...] mędrzec i głupiec, chory i zdrowy, rozpieszczany przez los i ciężko przez niego doświadczany - mają jednakową szansę, by odnaleźć sens życia. Będzie to sens na ich miarę skrojony ${ }^{11}$.

Umiejętność odnajdywania (szukania i nadawania) sensu według preferowanych wartości współdecyduje o jakości życia. Przeciwstawia chaosowi harmonię myśli, działania i wyniku tego działania. Charakteryzuje nastawienie człowieka wobec życia, drugiego człowieka i siebie.

W kręgu tych istotnych nastawień, współdecydujących o jakości życia, jest nastawienie wobec pracy. Obiektywna wartość pracy jest niepodważalna. Jej celem jest takie przekształcanie otaczającej rzeczywistości, by czynić ją użyteczną dla człowieka. Jan Paweł II w encyklice o pracy ludzkiej określił ją słowami:

Praca jest dobrem człowieka - dobrem jego człowieczeństwa - przez pracę bowiem człowiek nie tylko przekształca przyrodę, dostosowując ją do swoich potrzeb, ale także urzeczywistnia siebie jako człowiek, a także poniekąd bardziej „staje się człowiekiem”" ${ }^{\prime 2}$.

9 J. Czapiński, Osobowość szczęśliwego cztowieka, „Charaktery” 2004, nr 9, s. 25.

10 Tamże, s. 26.

11 Tamże.

12 Jan Paweł II, Laborem Exercens, w: Encykliki Ojca Świętego Jana Pawta II, Kraków 1997, s. 164. 
Praca jest więc dobrem osobowym i ekonomicznym, a pracowitość urasta do rangi sprawności moralnej, warunkującej dojrzałe formowanie własnego człowieczeństwa. S u b i e kt yw n a wartość pracy jest natomiast zróżnicowana: od negowania jej wartości i usiłowania życia na koszt innych, poprzez traktowanie pracy jako konieczności, aż po spostrzeganie jej jako sposobu bycia dla innych. Skutkiem tych nastawień jest zróżnicowanie jakości doświadczeń zawodowych: ich wysoka jakość dotyczy pozytywnych aspektów pracy: radości, entuzjazmu, twórczości ${ }^{13}$; natomiast niska - negatywnych: niezadowolenia, znudzenia, rutyny. Ma to istotne znaczenie zwłaszcza w tych zawodach, których miarą jest człowiek i jego życie. Do takich należy nauczycielstwo ${ }^{14}$. Celem artykułu jest empiryczna charakterystyka nastawień wobec pracy przyszłych nauczycieli-wychowawców oraz moralnych korelatów tych nastawień.

\section{Nastawienia wobec pracy}

Nastawienie decyduje o tym, co i jak człowiek spostrzega ${ }^{15}$. Jest odzwierciedleniem tego, co jest dla człowieka wartością ${ }^{16}$. Charakterystyczną cechą nastawień jest ich względna stałość, dzięki której można zrozumieć stałość spostrzegania i działania osoby ${ }^{17}$. Pedagog Wincenty Okoń określił nastawienie jako skłonność do spostrzegania i oceny ludzi, rzeczy i zdarzeń w sposób uwarunkowany dotychczasowymi doświadczeniami ${ }^{18}$.

Nastawienie wobec pracy decyduje o indywidualnym widzeniu siebie jako pracownika oraz sensu i wartości pracy. Jest pochodną nastawień wobec życia. Kryzysowa kondycja moralna współczesnego człowieka wskazuje na dwa - w aspekcie ogólnym

13 Por. I. Jazukiewicz, Pedeutologiczna teoria cnoty, dz. cyt., s. 203.

14 Por. J. Legowicz, O Nauczycielu mistrzu samego siebie, w: Pedeutologia. Badania i koncepcje metodologiczne, red. A. Kotusiewicz, H. Kwiatkowska, W. Zaczyński, Warszawa 1993, s. 18.

15 W. Beier, Pozytywne myślenie, przeł. M. Skalska, Warszawa 1997, s. 7.

16 R. Wilkins, Pozytywne myślenie... i co dalej, przeł. E. Jurewicz, Warszawa 1997, s. 11.

17 Por. I.T. Bżaława, Nastawienie - podstawa regulacji psychicznej, Warszawa 1970, s. 245.

18 W. Okoń, Stownik pedagogiczny, Warszawa 1975, s. 184. 
wyróżnione - nastawienia wobec życia: nastawienie na posiadanie i nastawienie na bycie. Są zróżnicowane według celu życia w zależności od tego, czy jest nim posiadanie bogactw, czy też bogactwo bycia. Aksjologiczną analizę tych dwóch podstawowych modusów istnienia przedstawił uznany niemiecki filozof, socjolog, psycholog i psychoanalityk Erich Fromm. O nastawieniu na posiadanie napisał:

Istota egzystencjalnego modus posiadania daje się wywieść $\mathrm{z}$ istoty własności prywatnej. W owym modus egzystencji liczy się tylko nabywanie własności i nieograniczone prawo do zatrzymania tego, co zdobyłem. [...] W modus posiadania nie daje się ufundować żaden żywy związek między mną a tym, co posiadam. Zarówno posiadany przedmiot, jak i ja stają się rzeczami, a ja posiada r z e c z, gdyż dysponuje siłą, dzięki której może uczynić ją swoją. Zachodzi tu również stosunek odwrotny: rzecz posiada mie $[\ldots]^{19}$.

Nastawienie na bycie uczony scharakteryzował następująco:

Warunkami wstępnymi modus bycia są niezależność, wolność i zdolność do krytycznego rozumowania. Jego podstawowe właściwości określa aktywne istnienie, przy czym aktywność nie oznacza tutaj działalności zewnętrznej, jak w przypadku biznesu, lecz wewnętrzną i chodzi w niej o twórcze wykorzystanie ludzkich możliwości. Bycie aktywnym urzeczywistnia się w swobodnym wyrazie swych talentów, zdolności, ogólnie mówiąc całego bogactwa darów, jakimi - w różnym stopniu - obdarzone są wszystkie istoty ludzkie. Dochodzi do głosu jako odnowa duchowa, rozwój, spontaniczna ekspresja samego siebie, miłość, przekraczanie ograniczonego więzienia własnego, izolowanego ja, zainteresowanie, [...] wreszcie jako dawanie ${ }^{20}$.

O wzajemnym związku obydwu egzystencjalnych nastawień wobec życia filozof napisał: "Tylko w takim stopniu, w jakim ograniczymy funkcjonowanie modus posiadania [...] - możemy uwolnić modus bycia. 'Być' wymaga rezygnacji z egocentryzmu i egoizmu [...]"21. Człowiek w swojej rozumności i wolności decyduje, którą ze swoich potencjalności urzeczywistnia. Jednym ze źródeł warunków umożliwiających realizację wybranej potencjalności jest praca. Człowiek szuka w pracy i poprzez pracę tych wartości i dóbr, które są adekwatne do jego egzystencjalnego modusu. Nastawienie wobec pracy jest istotnym elementem nastawienia wobec życia.

19 E. Fromm, Mieć czy być?, przeł. J. Karłowski, Poznań 2003, s. 133-134.

20 Tamże, s. 147-148.

21 Tamże, s. 148-149. 
Odpowiednio do powyższych modusów istnienia można wskazać dwa nastawienia wobec pracy: instrumentalne i podmiotowe. $\mathrm{Na}-$ stawienie instrumentalne ma miejsce wtedy, gdy człowiek postrzega pracę przez pryzmat wartości ekonomicznych, czyli preferuje treści związane $z$ kategorią mieć, posiadać. Praca umożliwia zaspokojenie potrzeby zdobywania niezbędnych środków materialnych oraz podwyższania standardu materialnego i społecznego. Nastawienie podmiotowe charakteryzuje osobę traktującą pracę jako źródło wartości związanych z treścią kategorii być, chcieć i działać. Praca pozwala więc zaspokoić potrzebę identyfikacji, tożsamości i kontaktów społecznych, umożliwia osiągnięcie określonego prestiżu społecznego oraz samorealizację osoby ${ }^{22}$. Znawca pedagogiki pracy Waldemar Furmanek wyróżnił na podstawie tego zróżnicowania następujące typy nastawień wobec pracy ${ }^{23}$ :

1.Praca jako konieczność życiowa człowieka wywołana przymusem ekonomicznym. Nastawienie to ma miejsce wtedy, gdy osoba traktuje pracę wyłącznie lub przede wszystkim jako źródło niezbędnych środków materialnych. Mniej istotny jest charakter i rodzaj pracy: może to być praca wykonywana w bardzo trudnych warunkach albo niezgodna z posiadanymi kwalifikacjami czy kompetencjami. Decyzja o jej podjęciu oraz poczucie odpowiedzialności pracownika są zdeterminowane motywami ekonomicznymi. Ważne jest wykonanie obowiązków w wyznaczonym czasie, a nie sens wykonywanej pracy. Człowiek nie poszukuje w niej radości ani spełnienia; traktuje ją instrumentalnie. $\mathrm{Na}$ ogół włożony wysiłek ocenia subiektywnie jako większy niż wartość wynagrodzeniu, a to sprzyja bardziej niezadowoleniu. Nie utożsamiania się więc z miejscem pracy. Można go zmienić w każdej chwili, jeśli tylko pojawi się oferta o większych walorach ekonomicznych. Pracownik nie dba o lojalność, na ogół prezentuje postawy roszczeniowe.

2. Praca jako obowiązek człowieka. Źródłem tego nastawienia jest przekonanie, że każdy, kto może pracować, jest do tego zobowiązany

22 W. Furmanek, Humanistyczna pedagogika pracy. Praca a jakośc życia cztowieka, Rzeszów 2016, s. 318.

23 W. Furmanek, Zarys humanistycznej teorii pracy, Torun 2008, s. 211-223; W. Furmanek, Rozumienie wartości pracy a orientacje życiowe cztowieka, „Pedagogika Pracy” 2004, nr 45, s. 62-66; por. I. Jazukiewicz, Pasja jako istotny wymiar doświadczania pracy, „Studia Paedagogica Ignatiana” 2017, nr 2, s. 89-91. 
dla pokazania swojej osobowej i społecznej przydatności. Konsekwencją jest traktowanie obowiązków pracy niezwykle solidnie i odpowiedzialnie. Są one jednak postrzegane instrumentalnie jako sposób podwyższenia standardu materialnego i społecznego. W odróżnieniu od poprzedniego nastawienia, przy wyborze pracy są jednak brane pod uwagę takie elementy, jak sens pracy, jej cele i warunki realizacji oraz własne możliwości. Sprzyja to poczuciu dobrego wyboru miejsca i charakteru pracy, przekładając się też na wysoki stopień lojalności i odpowiedzialności. Osoba przestrzega regulaminu pracy, stopniuje ważność zadań, oddziela pracę od innych sfer życiowej aktywności. Doświadcza tego, że jest dobrym pracownikiem, co mobilizuje ją do doskonalenia, a to z kolei jeszcze bardziej zwiększa satysfakcję, co skutkuje silnymi więziami z zawodem i miejscem pracy. Jest przesłanką do zmiany nastawienia wobec pracy z instrumentalnej na podmiotową.

3. Praca jako możliwość realizacji potrzeby identyfikacji i tożsamości osobowej. Nastawienie to jest przykładem podmiotowej interpretacji, która obejmuje rozumienie pracy jako formy zmieniania siebie i świata. Osoba o takim nastawieniu oczekuje od pracy nie tylko satysfakcji, lecz także możliwości własnego rozwoju. Jest odpowiedzialna za podejmowane zadania, ale też za siebie i wobec siebie. Systematycznie i wytrwale dąży do mistrzostwa w pracy, co współwystępuje z podnoszeniem stopnia identyfikacji społeczno-zawodowej. Sprzyja kształtowaniu nastawienia o jeszcze wyższym nasyceniu podmiotowości, czyli potraktowaniu pracy jako samorealizacji.

4. Praca jako droga i teren samorealizacji człowieka. Takie nastawienie oznacza odkrywanie samego siebie, swoich mocnych stron poprzez pracę. Dla osoby o tym nastawieniu naturalnym jest utożsamienie celów i planów zawodowych z życiowymi. Praca stanowi integralną część życia, a zadowolenie z jej wykonywania jest istotną częścią radości życiowej. Takie rozumienie pracy, ale też rozumienie siebie i otaczającej rzeczywistości, skutkuje korzystnymi z punktu widzenia osoby decyzjami: wyboru kierunku działania, doboru metod, form i środków realizacji zamierzeń. Jest ona umotywowana do działania, twórcza, traktuje trudności jako naturalne bariery, których pokonanie jest ważnym elementem rozwoju. Praca jako przestrzeń realizowania własnych dążeń i wyrażania siebie nie jest formą aktywności 
rozdzielną z wypoczynkiem. Warunkiem owocności tego nastawienia jest adekwatne rozpoznanie swoich możliwości i zainteresowań.

5. Praca jako oznaka prestiżu społecznego. Źródłem tego nastawienia są aspiracje osoby do zajmowania określonej pozycji społecznej. Treść pracy różnicuje jej znaczenie osobowe i społeczne, wpływając na tę pozycję. W procesie wychowania człowiek poznaje to zróżnicowanie, więc wybiera taką drogę kształcenia, która umożliwia mu zdobycie kwalifikacji adekwatnych do jego aspiracji w tym zakresie. Praca ma przez to szansę stać się przestrzenią samorozwoju i uzyskania oczekiwanego prestiżu społecznego.

6. Praca jako szansa na budowanie więzi społecznych oraz możliwość zaspokojenia potrzeby kontaktów społecznych. Źródłem takiego nastawienia jest bardzo silna potrzeba kontaktów społecznych. Stanowi ona podstawowy motyw wyboru i podejmowania pracy. Może charakteryzować np. osoby na emeryturze lub rencie, które z własnej woli nie zamierzały jeszcze zaprzestać aktywności zawodowej i w związku z tym silnie odczuwają nagłą zmianę trybu życia, między innymi ograniczenie kontaktów interpersonalnych. Nastawienie tego typu może też być reprezentowane przez osoby, które $\mathrm{z}$ innego powodu nie pracują, np. kobiety prowadzące gospodarstwa domowe. Takie nastawienie może skutkować podejmowaniem pracy nieadekwatnej do swoich zainteresowań lub możliwości albo bardzo nisko uposażanej, ponieważ najważniejsza w pracy jest dla osoby możliwość bycia w kontakcie $\mathrm{z}$ innymi.

Nastawienie wobec pracy decyduje o sposobie jej doświadczania. Jeśli praca jest źródłem zaspokajania zróżnicowanych potrzeb, to człowiek doświadcza jej jako wartości związanej z realizacją życiowych celów, a więc także z poczuciem sensu życia. Stopień zadowolenia $\mathrm{z}$ wykonywanej pracy wydaje się być adekwatny do stopnia realizowania dzięki niej życiowych planów i marzeń.

\section{Moralne korelaty nastawień wobec pracy}

Stosunek wobec pracy jest stosunkiem do wartości ${ }^{24}$. W związku z tym problematyka nastawień ma swój wymiar moralny. Słusznym jest mówić o wpływie pracy na moralność oraz o wpływie moralności

24 W. Furmanek, Humanistyczna pedagogika pracy. Praca a jakośc życia cztowieka, dz. cyt., s. 317. 
na wykonywaną pracę ${ }^{25}$. Uzasadnione jest także poszukiwanie związku pomiędzy nastawieniem człowieka wobec pracy a jego wartościami.

Interesującą typologię wartości przedstawił psycholog Józef Kozielecki. Jest to podział mniej powszechny, ale niezwykle „plastyczny” w opisie ze względu na nazewnictwo nawiązujące do mitologii. Autor wyróżnił następujące typy indywidualnych wartości ${ }^{26}$ :

1. Wartości dionizyjskie. Charakteryzują człowieka, który najwyżej ocenia takie dobra, jak konsumpcja, komfort, wygodne życie. Dąży do życia pełnego radości i satysfakcji. Uważa, że należy brać z życia jak najwięcej, korzystając ze zdobyczy współczesnej cywilizacji przemysłowej. Życie ma sens tylko wtedy, gdy obfituje w konsumpcyjną obfitość.

2. Wartości heraklesowe. Charakteryzują człowieka, który dąży do dominacji nad innymi ludźmi, do zdobycia władzy i sławy. Komfort i wygody nie są tak ważne, jak kontrola nad otoczeniem, grupami i strukturami społecznymi. Zachowanie osoby zdeterminowane jest myśleniem o tym, jak zdobyć władzę i uznanie.

3. Wartości prometejskie. Charakteryzują człowieka, który widzi siebie jako cząstkę wspólnoty. Często i chętnie podejmuje działania prospołeczne i altruistyczne. Walka z cierpieniem, złem, okrucieństwem, represjami ma dla niego najwyższą wartość osobistą.

4. Wartości apollińskie. Charakteryzują człowieka, który największe znaczenie przypisuje twórczości i innowacyjności, poznawaniu świata, rozwojowi nauki i sztuki. Wartości te zwiększają szansę przetrwania kultury i cywilizacji. Dla hierarchii apollińskiej najważniejsze jest pytanie o to, jak poznawać i zmieniać świat zewnętrzny.

5. Wartości sokratyczne. Charakteryzują człowieka, dla którego najwyższym dobrem jest poznawanie i rozumienie samego siebie oraz doskonalenie własnej osobowości. Życie jest sensowne i wartościowe, jeśli pozwala tworzyć osobowość wszechstronnie rozwiniętą, stąd największą radość daje ciągły rozwój, samokształcenie i samodoskonalenie. Dla hierarchii sokratycznej najważniejsze jest pytanie o to, jak poznawać i projektować samego siebie.

Poznanie wartości człowieka ma istotne znaczenie dla zrozumienia mechanizmów jego myślenia i działania, bowiem pozwala

25 Tamże, s. 325.

26 J. Kozielecki, Koncepcje psychologiczne cztowieka, Warszawa 1995, s. 223-225. 
wyjaśnić, dlaczego osoba dąży do pewnych stanów, a innych unika ${ }^{27}$. Znając preferowany przez nią sposób wartościowania, można więc przewidzieć jej styl (nastawienie wobec) życia ${ }^{28}$. W związku z tym można też wnioskować o związku jej hierarchii wartości z nastawieniem wobec pracy.

Nie można mówić o moralności bez uwzględnienia emocji, ponieważ odgrywają one istotną rolę $\mathrm{w}$ odczuwaniu wartości ${ }^{29}$. Istnieją teoretyczne i empiryczne dowody na współwystępowanie właściwości dojrzałości emocjonalnej i przejawów prawidłowego funkcjonowania moralnego. Osoby dojrzałe emocjonalnie charakteryzuje umiejętność udzielania się otoczeniu, brak agresywności, większa zdolność do dawania niż do brania, życie w zgodzie z potrzebą miłości, przewaga uczuć skierowanych na innych nad uczuciami skierowanymi na siebie, co wiąże się z gotowością pomocy. Ludzie moralni są bardziej dojrzali emocjonalnie i społecznie, reagują emocjami adekwatnie co do znaku oraz z proporcjonalnym natężeniem do moralno-społecznej wartości sytuacji i życiowego znaczenia źródła emocji ${ }^{30}$. Według psychologa moralności Włodzimierza Strusa dojrzałość emocjonalna jest jednym z wyznaczników potencjału regulacyjnego świadomości moralnej i warunkiem efektywnej samokontroli ${ }^{31}$. Zdaniem tego autora:

[...] po pierwsze, poziom dojrzałości emocjonalnej warunkuje jakość i adekwatność odczuwania moralnego. Innymi słowy, od poziomu dojrzałości emocjonalnej zależy stopień rozwoju i jakość funkcjonowania sumienia emocjonalnego. Efektem niedojrzałości emocjonalnej jest m.in. brak albo dysfunkcjonalność uczuć moralnych, a dalej utrata regulacyjnego potencjału sumienia emocjonalnego lub jego dezadaptacyjna dominacja (niemoralne lub sztywne zachowanie). Tę ścieżkę wpływu nazywamy specyficzną. Po drugie, emocjonalność wpływa na funkcjonowanie moralne niespecyficznie, określając w znacznej mierze ogólny poziom samokontroli jednostki, zwyczajny (tj. najczęstszy, przeważający) stan pola świadomości (np. dominujący nastrój, przewaga określonych stanów emocjonalnych) oraz determinując w istotnym stopniu ogólny poziom koherencji (integracji) osobowości [...]. W ten

J. Kozielecki, Koncepcje psychologiczne cztowieka, dz. cyt., s. 216. Por. tamże, s. 225. W. Strus, Dojrzatośc emocjonalna a funkcjonowanie moralne, Stare Kościeliska 2012, s. 166.

31 Tamże, s. 169. 
sposób poziom dojrzałości emocjonalnej warunkuje szanse uwzględnienia przez jednostkę zazwyczaj dość subtelnych (w porównaniu np. z impulsami popędowymi czy naciskami zewnętrznymi) norm moralnych w swoim codziennym myśleniu, doświadczaniu i postępowaniu. Innymi słowy, udział sumienia w myślach, przeżyciach emocjonalnych i całości życia motywacyjnego osoby dojrzałej emocjonalnie będzie większy (częstszy), gdyż nie będzie ono napotykało tak wielu trudności w przebiciu się ze swoim głosem, jak to dzieje się u osoby niedojrzałej. Dojrzałość w sferze emocjonalnej ułatwia funkcjonowanie moralne w tym sensie, że wiąże się ze zwiększeniem wpływu sumienia na zachowanie kosztem zmiennych sytuacyjnych oraz impulsów popędowych. W efekcie dojrzałość emocjonalna przekłada się na nasilenie postępowania moralnego ${ }^{32}$.

Włodzimierz Strus jest autorem koncepcji badań uczuć moralnych o stosunkowo szerokim zakresie. Została ona wykorzystana w poniższych badaniach.

\section{Metoda}

Uwzględniając przesłanki teoretyczne, celem badań uczyniono sprawdzenie korelacji między nastawieniem wobec pracy a wartościami i uczuciami moralnymi studentów pedagogiki. Sformułowano następujący problem badawczy: Czy istnieje związek pomiędzy nastawieniem wobec pracy a wartościami i uczuciami moralnymi studentów pedagogiki? Przyjęto hipotezę, że zachodzi istotny statystycznie związek pomiędzy nastawieniem wobec pracy a wartościami i uczuciami moralnymi badanych osób.

Model korelacyjny obejmuje zmienne współwystępujące. W tym przypadku są nimi: 1) Typy nastawień wobec pracy. Dla celów badawczych przyjęto następujące typy: praca jako konieczność, praca jako powinność społeczna, praca jako możliwość realizacji potrzeby identyfikacji i tożsamości osobowej, praca jako samorealizacja człowieka, praca jako prestiż społeczny, praca jako zaspokojenie potrzeby kontaktów społecznych. 2) Typy wartości. Dla celów badawczych przyjęto następujące typy wartości: dionizyjskie, heraklesowe, prometejskie, apolińskie, sokratyczne. 3) Skala uczuć moralnych. Dla celów badawczych przyjęto dwie podskale: przekraczanie norm i realizowanie norm. Wskaźnikiem zmiennych

Tamże. 
współwystępujących były wartości liczbowe uzyskane przez badanego w stosownych kwestionariuszach.

\section{Narzędzia badawcze}

W celu zbadania typów nastawień wobec pracy studentów pedagogiki zastosowano autorską listę twierdzeń. Lista składa się z 36 twierdzeń (po 6 dla każdego typu nastawienia), dotyczących pracy zawodowej. Zadaniem badanego było określić, na ile zgadza się $\mathrm{z}$ danym twierdzeniem $\mathrm{w}$ zakresie pięciu możliwych odpowiedzi: zdecydowanie nie zgadzam się $\mathrm{z}$ twierdzeniem; nie zgadzam się z twierdzeniem; trudno powiedzieć; zgadzam się z twierdzeniem; zdecydowanie zgadzam się z twierdzeniem.

W celu zbadania typów wartości studentów pedagogiki zastosowano autorską listę twierdzeń. Lista składa się z 35 twierdzeń (po 7 dla każdego typu nastawienia), dotyczących wartości życiowych. Zadaniem badanego było określić, na ile zgadza się z danym twierdzeniem w zakresie pięciu możliwych odpowiedzi: zdecydowanie nie zgadzam się $\mathrm{z}$ twierdzeniem; nie zgadzam się $\mathrm{z}$ twierdzeniem; trudno powiedzieć; zgadzam się $\mathrm{z}$ twierdzeniem; zdecydowanie zgadzam się z twierdzeniem.

W celu zbadania uczuć badanych osób w sytuacjach moralnych zastosowano Skale Uczuć Moralnych (SUM-5) autorstwa Włodzimierza Strusa. Jest to standaryzowane narzędzie do pomiaru skłonności do doświadczania różnych uczuć w sytuacjach przekraczania i realizowania subiektywnie ważnych norm moralnych ${ }^{33}$. Adekwatnie do tego SUM składa się z części A i części B. W pierwszej z nich badany jest proszony o przypomnienie sobie sytuacji, w której przekroczył ważną dla siebie normę moralną, a następnie, by zaznaczył na liście wymienionych uczuć częstotliwość ich przeżywania (w tej sytuacji oraz w innych sytuacjach, w których naruszał ważne dla siebie normy moralne) na siedmiostopniowej skali od „nigdy” do „zawsze”. Część B skonstruowana jest analogicznie, tyle że odnosi się do sytuacji przestrzegania subiektywnie ważnych norm.

W wersji SUM-5 część A, badająca nasilenie dyspozycji do doświadczania określonych uczuć w sytuacjach naruszania norm

33 W. Strus, Skala Uczuć Moralnych (SUM): konstrukcja i wtaściwości psychometryczne, „Studia Psychologica”2010, nr 10, s. 275. 
moralnych, składa się z 6 skal. Pierwsze trzy skale dotyczą reakcji emocjonalnych związanych $z$ niskim poziomem internalizacji norm, natomiast kolejne trzy wiążą się z wyższym poziomem tego procesu. Są to ${ }^{34}$ :

1. Skala uczuć pozytywnych (AUP) - mierzy tendencję do przeżywania przyjemnych stanów emocjonalnych (związanych z gratyfikacją amoralnych motywów).

2. Skala uczuć eksternalizacyjnych i dystansowania się od odpowiedzialności (AUE) - odnosi się do obojętności i uczuć wynikających z nieprzyjmowania odpowiedzialności za transgresję moralną na siebie (brak atrybucji wewnętrznej) albo przypisywania jej komuś lub czemuś innemu (atrybucja zewnętrzna).

3. Skala strachu przed karą (ASK) - odzwierciedla przeżycia znamionujące się niepokojem i lękiem przed zewnętrznymi konsekwencjami własnej transgresji moralnej.

4. Skala wstydu (AWS) - uczucia związane z zaabsorbowaniem negatywną oceną innych.

5. Skala globalnego poczucia winy (AGW) - dysfunkcjonalne poczucie winy.

6. Skala poczucia skruchy (APS) - funkcjonalne poczucie winy.

Część B, badająca nasilenie dyspozycji do doświadczania określonych uczuć w sytuacjach przestrzegania norm moralnych, składa się z następujących pięciu skal ${ }^{35}$ :

1. Skala uczuć negatywnych (BUN) - mierzy skłonność do doświadczania ujemnych stanów emocjonalnych (wyrażających konflikt lub frustrację podmiotu) w obliczu przestrzegania norm.

2. Skala nadziei na nagrodę (BNN) - ocenia nasilenie tendencji do przeżywania uczuć związanych z oczekiwaniem dodatkowych wzmocnień zewnętrznych w sytuacjach realizowania norm.

3. Skala pychy (BPY) - uczucia związane z globalną, pozytywną ewaluacją ja i poczuciem wyższości wobec innych.

4. Skala uczuć pozytywnych (umacnianie siebie) (BUP) - uczucia pozytywne związane z poczuciem siły, spełnienia i zadowoleniem ze swojego osiągnięcia, duma.

34 W. Strus, P.O. Żylicz, Emocje samoświadomościowe-podstawowe rozróżnienia i narzędzia pomiaru, w: Metody badania emocji i motywacji, red. H. Gasiul, Warszawa 2018, s. 102.

35 Tamże, s. 102. 
5. Skala powinności wobec zasad (BPZ) - mierzy skłonność do doświadczania uczuć wyrażających koncentrację na przestrzeganych normach, nie zaś na ja i własnych osiągnięciach.

Skale części A zwierają po cztery pozycje, z wyjątkiem skali globalnego poczucia winy, która składa się z sześciu. W części B każda skala zawiera pięć pozycji. W sumie więc Skala Uczuć Moralnych (SUM-5) zawiera 51 pozycji (26 w części A oraz 25 w części B) tworzących 11 skal. Weryfikacja podstawowych właściwości psychometrycznych potwierdziła zadowalającą rzetelność wszystkich skal SUM-5 $5^{36}$.

\section{Grupa}

Badania przeprowadzono w okresie od grudnia 2017 do lutego 2018 roku. Objęto nimi grupę 227 studentów pedagogiki Uniwersytetu Szczecińskiego, przy czym 5 osób zostało wykluczonych ze względu na to, że nie wypełniły więcej niż jednego z trzech kwestionariuszy. Pojedyncze braki w odpowiedziach (maksymalnie 3 dla jednej osoby) zostały uzupełnione o wartości średnie. Ostatecznie w badanej grupie znalazło się 222 studentów (w tym 94,6\% kobiet) w wieku od 19 do 48 lat. Średnia wieku wynosiła M=22,96 przy odchyleniu standardowym równym $\mathrm{SD}=5,30$.

\section{Analiza uzyskanych wyników}

Statystyczną analizę danych wykonano w pakiecie IBM SPSS Statistics v.25. Zastosowano techniki opisu statystycznego i test normalności rozkładu Shapiro-Wilka w celu oceny czy uzyskane w badaniu rozkłady wyników są zbliżone do rozkładu normalnego, typowego dla ogólnej populacji. Aby zweryfikować założenia o związkach pomiędzy badanymi zmiennymi, zastosowano metodę korelacji parami ze współczynnikiem rho Spearmana. Za wskaźnik istotności statystycznej przyjęto wartość $\mathrm{p}<0,05$, a wartość $\mathrm{p}<0,1$ przyjęto za wskaźnik nie w pełni istotnej tendencji statystycznej. 


\section{Nastawienia wobec pracy wśród studentów pedagogiki}

Badani studenci cechowali się głównie nastawieniem do pracy jako sposobu na samorealizację, zaś w najmniejszym stopniu - jako oznaki prestiżu społecznego i konieczności. Wyniki tego pomiaru zawarto w tabeli 1.

Tabela 1. Podstawowe parametry rozkładu wyników pomiaru nastawienia do pracy badanych studentów pedagogiki $(\mathrm{N}=222)$

\begin{tabular}{|l|c|c|c|c|c|}
\hline $\begin{array}{c}\text { Nastawienie } \\
\text { do pracy jako: }\end{array}$ & Minimum & Maksimum & Średnia & $\begin{array}{c}\text { Odchylenie } \\
\text { standardowe }\end{array}$ & $\begin{array}{c}\text { Normalność } \\
\text { rozkładu }\end{array}$ \\
\hline Konieczności & 2 & 24 & 12,26 & 4,21 & 0,108 \\
\hline Powinność społecznej & 0 & 24 & 15,06 & 3,46 & $<0,001$ \\
\hline Identyfikacji i tożsamości & 1 & 24 & 16,40 & 3,47 & $<0,001$ \\
\hline Oznaki prestiżu społecznego & 0 & 24 & 11,71 & 3,96 & 0,008 \\
\hline Samorealizacji & 4 & 24 & 19,85 & 3,03 & $<0,001$ \\
\hline Kontaktów społecznych & 1 & 24 & 16,75 & 3,85 & $<0,001$ \\
\hline
\end{tabular}

Źródło: opracowanie własne.

Nieistotny $(\mathrm{p}<0,05)$ wynik testu normalności rozkładu oznacza, że uzyskany w badaniu rozkład wyników nie różni się od typowego dla ogólnej populacji, czyli dominują w nim wyniki przeciętne, zaś niższe i wyższe występują sukcesywnie rzadziej. Takim kształtem cechował się tylko rozkład wyników pomiaru nastawienia do pracy jak do konieczności, który zawarto na wykresie 1 . Nieco mniej wyraźnie, ale również $\mathrm{w}$ pomiarze tendencji do poszukiwania w pracy oznak prestiżu, przeważały wyniki przeciętne, a niskie i wysokie nasilenie występowało równie rzadko (wykres 4 ). $Z$ kolei w pozostałych pomiarach zdecydowanie dominowały wyniki powyżej przeciętnej (wykresy 2, 3, 6), a w ocenie pracy jako samorealizacji najczęściej występowały wyniki wysokie (wykres 5). 
Wykres 1.

Rozkład wyników pomiaru pracy jako konieczności

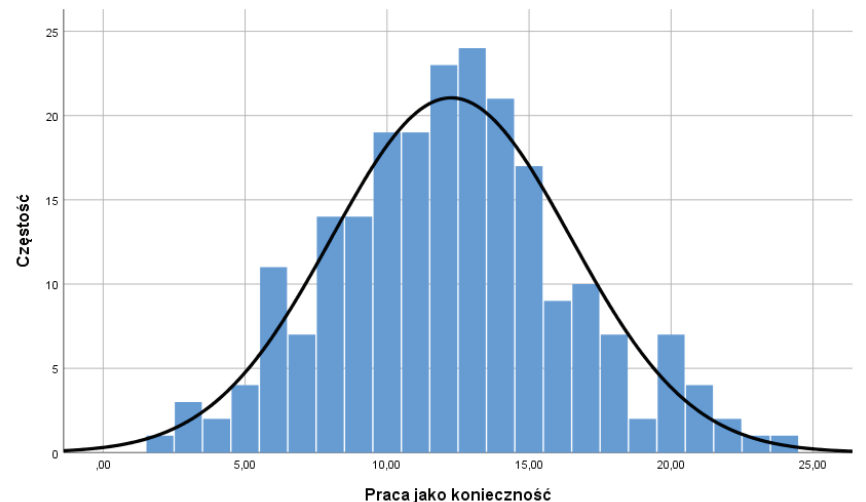

Źródło: opracowanie własne.

Wykres 2.

Rozkład wyników pomiaru pracy jako powinności społecznej

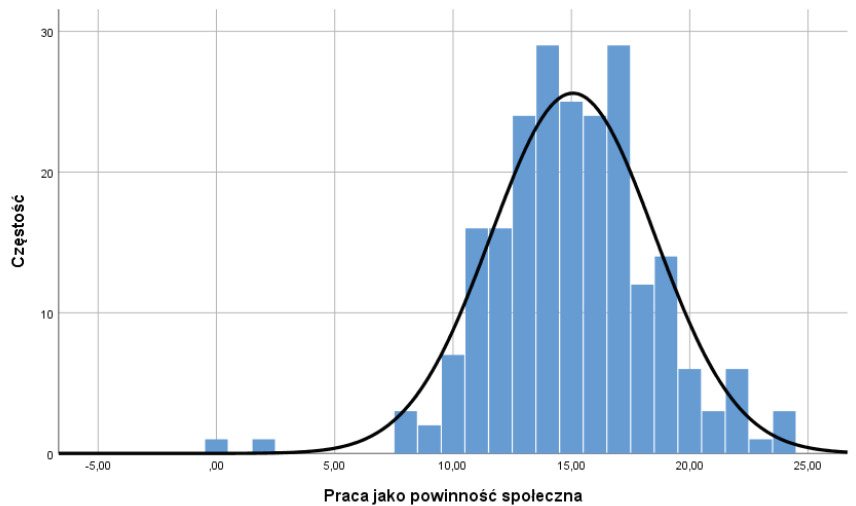

Źródło: opracowanie własne.

Wykres 3. Rozkład wyników pomiaru pracy jako realizacji potrzeby identyfikacji i tożsamości osobowej

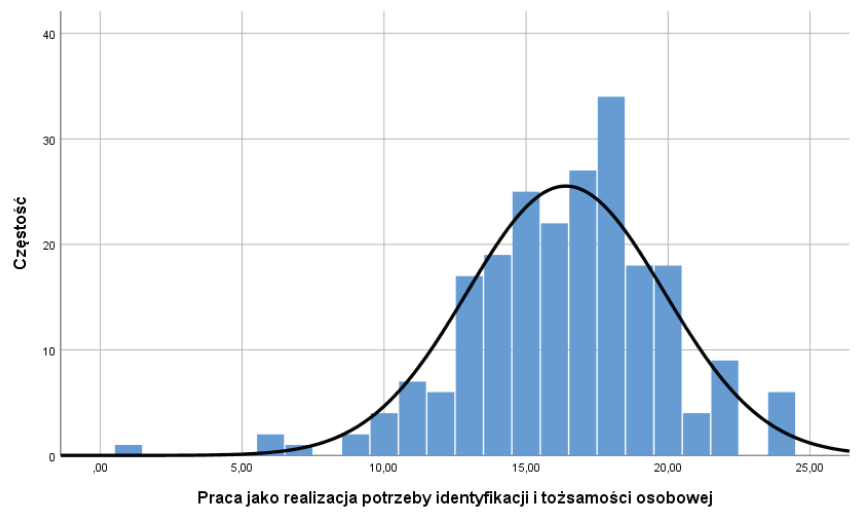

Źródło: opracowanie własne. 


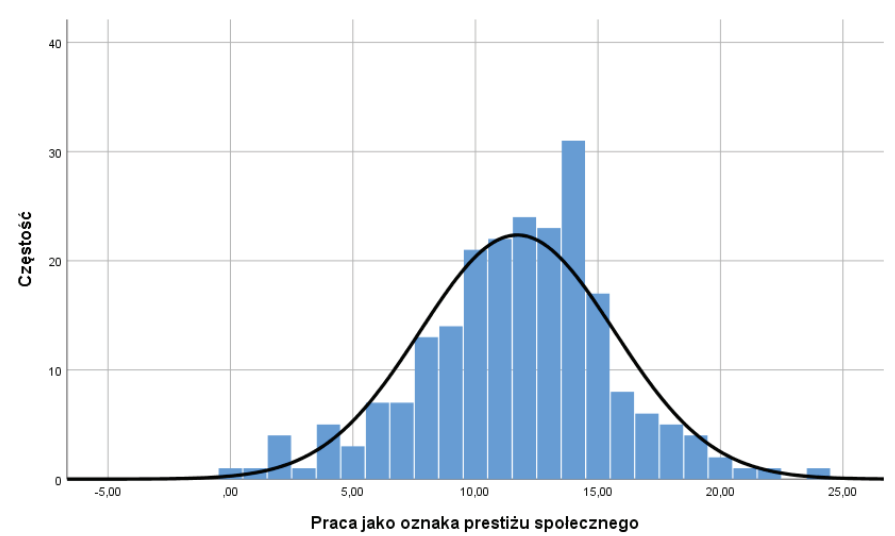

Źródło: opracowanie własne.

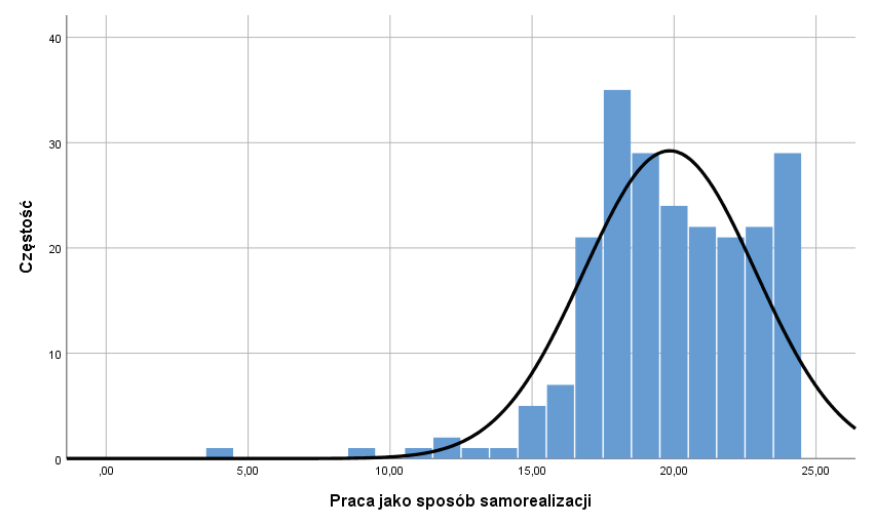

Źródło: opracowanie własne.

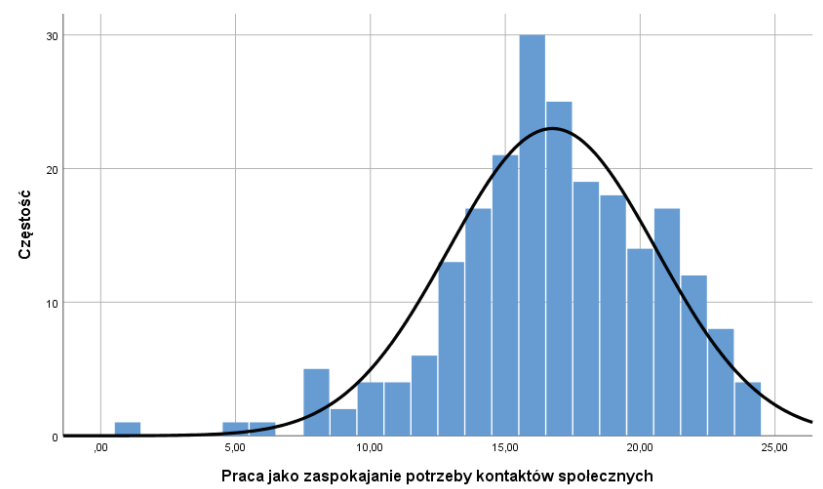

Źródło: opracowanie własne.
Wykres 4.

Rozkład wyników pomiaru pracy jako oznaki prestiżu społecznego

Wykres 5.

Rozkład wyników pomiaru pracy jako sposobu samorealizacji

Wykres 6.

Rozkład wyników pomiaru pracy jako zaspokajania potrzeby kontaktów społecznych 
Objęci badaniem studenci pedagogiki cechowali się zatem postrzeganiem pracy jako możliwości realizowania swojego potencjału, zainteresowań i zamierzeń. Najmniej koncentrowali się na tym, że praca jest życiową koniecznością oraz kryterium społecznego zróżnicowania w postaci prestiżu.

\section{Wartości studentów pedagogiki}

W tabeli 2 zawarto informacje o wynikach uzyskanych w pomiarze listą twierdzeń wartości.

Tabela 2. Podstawowe parametry rozkładu wyników pomiaru wartości badanych studentów pedagogiki $(\mathrm{N}=222)$

\begin{tabular}{|l|c|c|c|c|c|}
\hline Typ wartości: & Minimum & Maksimum & Średnia & $\begin{array}{c}\text { Odchylenie } \\
\text { standardowe }\end{array}$ & $\begin{array}{c}\text { Normalność } \\
\text { rozkładu }\end{array}$ \\
\hline Dionizyjskie & 2 & 25 & 13,19 & 4,53 & 0,041 \\
\hline Heraklesowe & 0 & 26 & 8,90 & 5,07 & $<0,001$ \\
\hline Prometejskie & 11 & 28 & 22,87 & 3,06 & $<0,001$ \\
\hline Apollińskie & 6 & 28 & 20,33 & 3,82 & $<0,001$ \\
\hline Sokratyczne & 15 & 28 & 23,57 & 2,87 & $<0,001$ \\
\hline
\end{tabular}

Źródło: opracowanie własne.

Najbardziej nasilonymi wartościami wśród badanych studentów były wartości sokratyczne (średnio niemal 24 punkty) oraz prometejskie (średnio niemal 23 punkty), zaś najmniej nasilone wartości heraklesowe (blisko 9 punktów). Wszystkie rozkłady odbiegały od normalnego, chociaż najbardziej zbliżony do obrazu ogólnej populacji był rozkład wartości dionizyjskich. Zatem większość studentów cechowała się przeciętnym wartościowaniem wygód życiowych i dóbr materialnych (wykres 7). W pomiarze wartości heraklesowych przeważały osoby o poniżej przeciętnych wynikach, a studentów wysoko wartościujących władzę i dominację było zdecydowanie mniej (wykres 8). W odniesieniu do wartości apollińskich, większość studentów cechowała się ich podwyższonym wartościowaniem, chociaż zdarzały się także osoby raczej nisko ceniące takie dobra, jak sztuka, piękno, kreatywność (wykres 10). Z kolei wartości prometejskie i sokratyczne były cenione przez większość badanych w stopniu wysokim - w tych pomiarach nie odnotowano żadnych wyników niskich, a maksymalne wyniki występowały z dość wysoką częstotliwością (wykresy 9 i 11). 


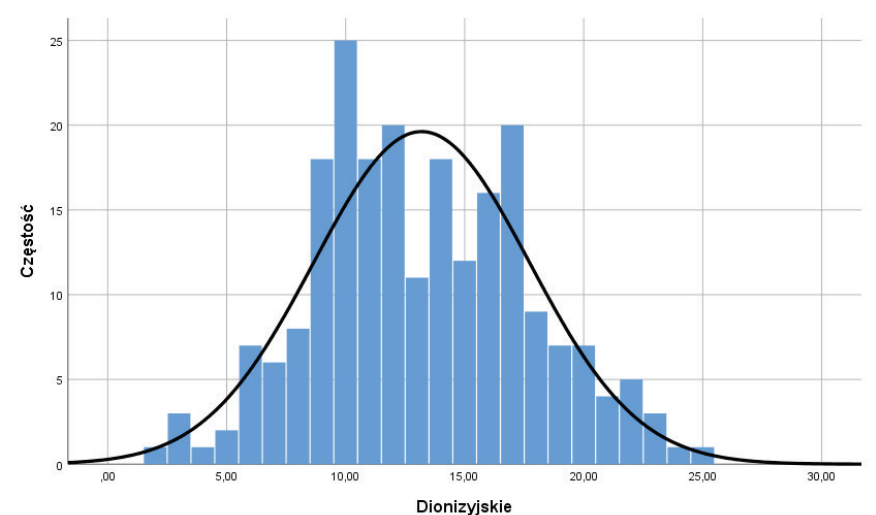

Źródło: opracowanie własne.

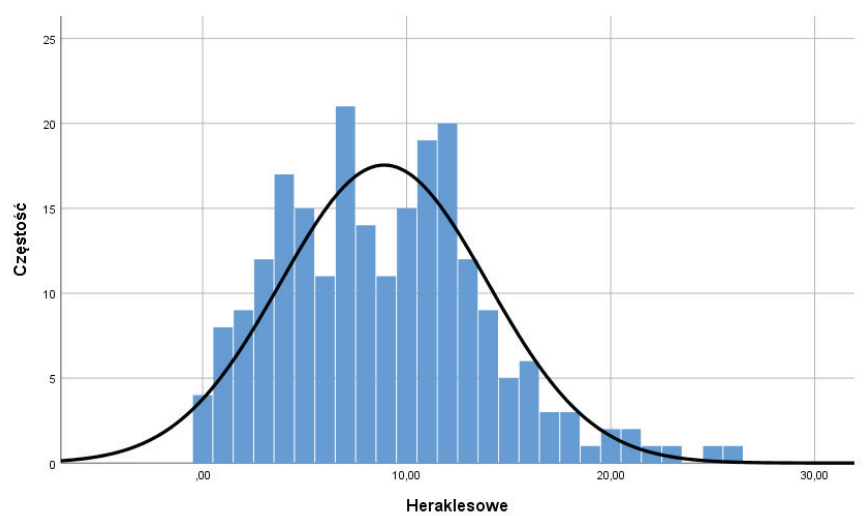

Źródło: opracowanie własne.

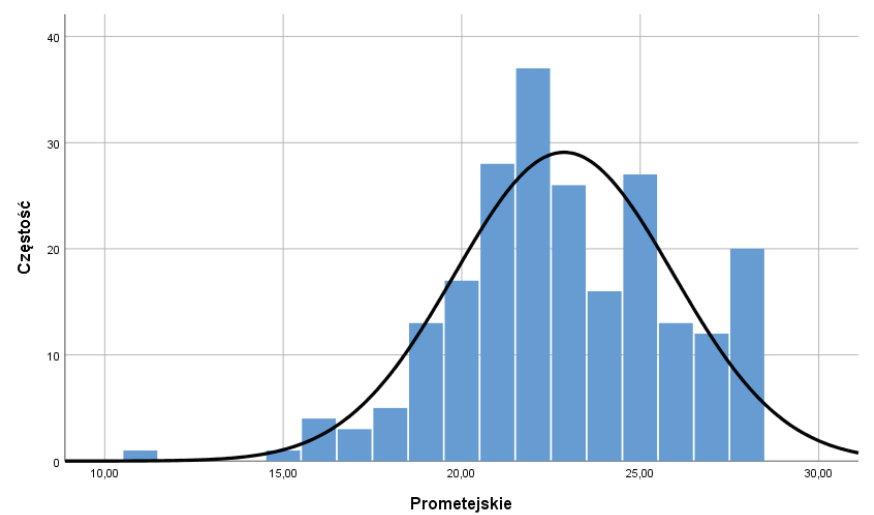

Źródło: opracowanie własne.
Wykres 7.

Rozkład wyników pomiaru wartości dionizyjskich

Wykres 8.

Rozkład wyników pomiaru wartości heraklesowych

Wykres 9.

Rozkład wyników pomiaru wartości prometejskich 
Wykres 10. Rozkład wyników pomiaru wartości apollińskich

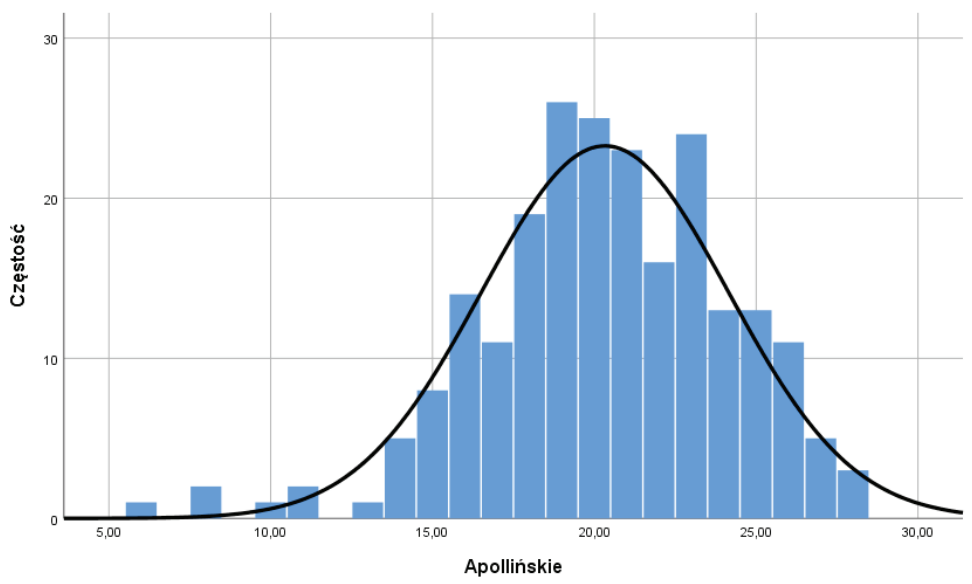

Źródło: opracowanie własne.

Wykres 11.

Rozkład wyników pomiaru wartości sokratycznych

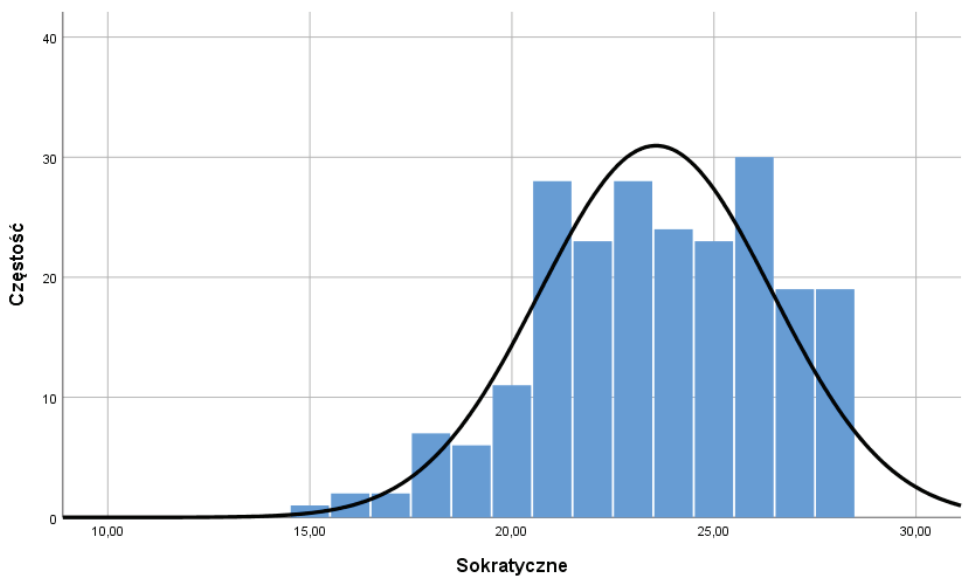

Źródło: opracowanie własne.

Objęci badaniem studenci pedagogiki cechowali się zatem raczej wysokim wartościowaniem wiedzy i poznania oraz pomocy innym ludziom, a często też dążeniem do piękna, harmonii i tworzenia. Ponadto, przeciętnym wartościowaniem dóbr konsumpcyjnych i wygód życia oraz raczej obniżonym dążeniem do dominacji i posiadania władzy nad innymi ludźmi. 


\section{Uczucia w sytuacjach moralnych studentów pedagogiki}

W pomiarze uczuć moralnych również dominowały pozytywne wartości związane z realizowaniem norm. Rozkład wyników przedstawiono w tabeli 3.

Tabela 3. Podstawowe parametry rozkładu wyników pomiaru uczuć moralnych wśród badanych studentów pedagogiki $(\mathrm{N}=216)$

\begin{tabular}{|c|c|c|c|c|c|}
\hline $\begin{array}{c}\text { Uczucia } \\
\text { moralne }\end{array}$ & Minimum & Maksimum & Średnia & $\begin{array}{c}\text { Odchylenie } \\
\text { standardowe }\end{array}$ & $\begin{array}{c}\text { Normalność } \\
\text { rozkładu }\end{array}$ \\
\hline AUP & 0 & 21 & 10,39 & 4,16 & 0,038 \\
\hline AUE & 2 & 20 & 11,56 & 3,46 & 0,016 \\
\hline ASK & 2 & 24 & 13,41 & 4,34 & 0,139 \\
\hline AWS & 0 & 24 & 9,29 & 5,36 & 0,002 \\
\hline AGW & 0 & 30 & 15,23 & 4,46 & 0,003 \\
\hline APS & 3 & 24 & 14,68 & 3,94 & 0,042 \\
\hline BUN & 2 & 29 & 14,12 & 4,34 & 0,071 \\
\hline BNN & 6 & 26 & 17,33 & 3,60 & 0,050 \\
\hline BPY & 3 & 30 & 17,07 & 5,22 & 0,017 \\
\hline BUP & 1 & 30 & 17,29 & 4,58 & 0,008 \\
\hline BPZ & 4 & 25 & 14,71 & 3,85 & 0,144 \\
\hline
\end{tabular}

A - przekraczanie norm, $B$ - realizowanie norm, AUP - uczucia pozyływne, AUE - uczucia eksternalizacyine i dystansowanie się od odpowiedzialności, ASK - strach przed karq, AWS - wstyd, AGW - globalne poczucie winy, APS - poczucie skruchy, BUN - uczucia negatywne, $B N N$ - nadzieja na nagrodę, $B P Y$ - pycha, $B U P$ uczucia pozyływne (umacnianie siebie), BPZ - powinność wobec zasad.

Źródło: opracowanie własne.

Badani studenci cechowali się największym nasileniem nadziei na nagrodę (BNN), pychy (BPY) i uczuć pozytywnych (BUP), osiągając średnio ponad 17 punktów. Są to uczucia doświadczane w sytuacjach przestrzegania norm moralnych. Z kolei najmniej nasilone były uczucia w sytuacjach naruszania norm moralnych: wstyd (AWS), uczucia pozytywne (AUP) oraz uczucia eksternalizacyjne i dystansowania się od odpowiedzialności (AUE). Tylko rozkłady powinności wobec zasad (BPZ) i strachu przed karą (ASK) uznać można za zgodne 
z rozkładem ogólnej populacji, co zobrazowano na wykresach 14 i 22. Odchylenia pozostałych rozkładów powodowane były głównie przewagą osób wykazujących przeciętne nasilenie danych uczuć i nieproporcjonalnie mniejszy odsetek osób osiągających skrajnie niskie i wysokie oceny. Dokładne informacje o nasileniu poszczególnych uczuć moralnych wśród badanych studentów pedagogiki przedstawiono na poniższych wykresach.

Wykres 12. Rozkład wyników pomiaru uczuć pozytywnych

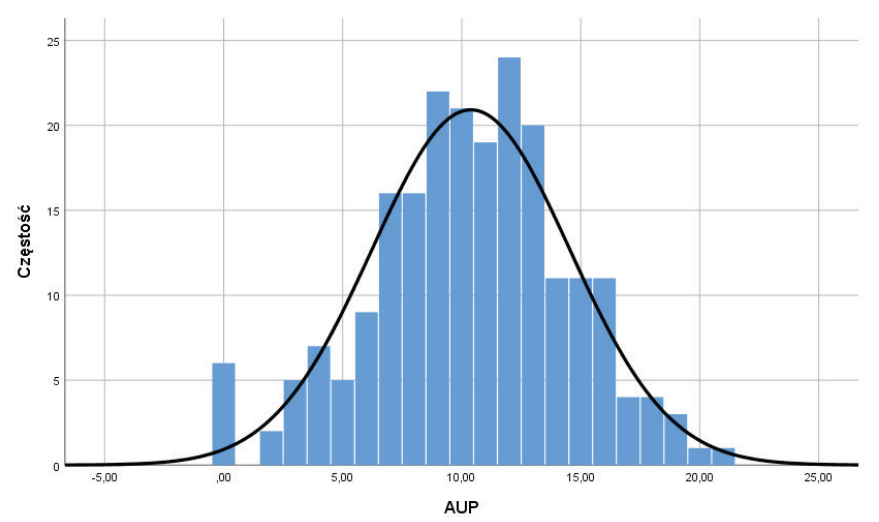

Źródło: opracowanie własne.

Wykres 13. Rozkład wyników pomiaru uczuć eksternalizacyinych i dystansowania się od odpowiedzialności

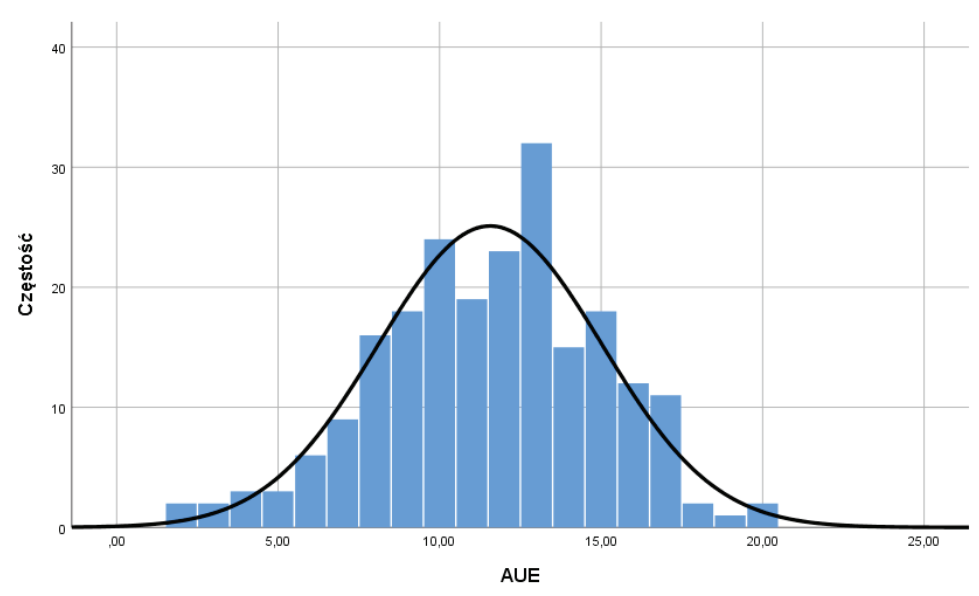

Źródło: opracowanie własne. 


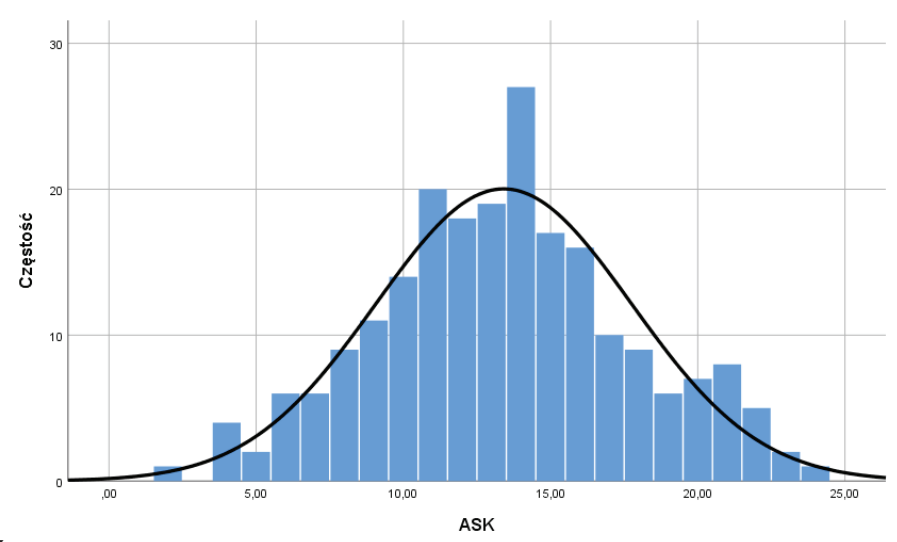

Źródło: opracowanie własne.

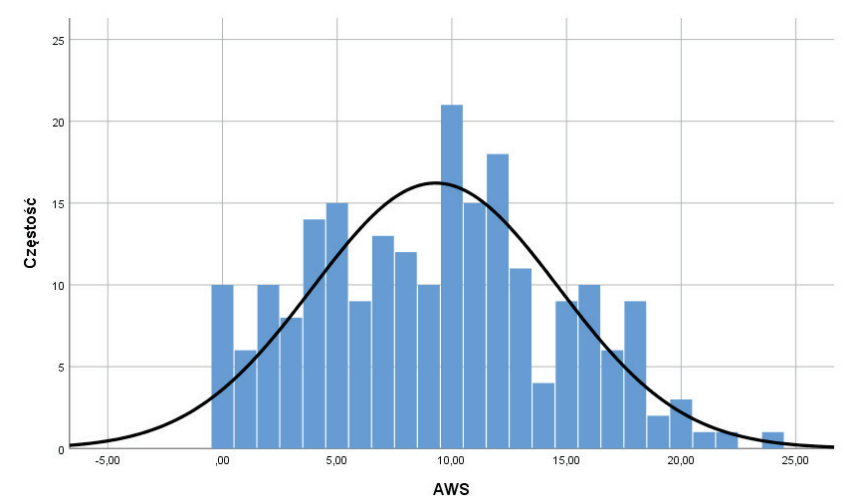

Źródło: opracowanie własne.

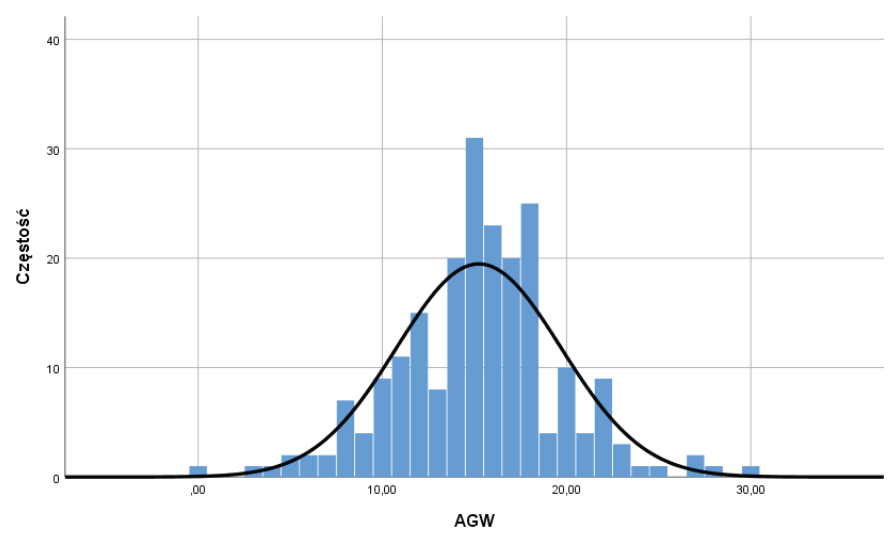

Wykres 14.

Rozkład wyników pomiaru strachu przed karq

Wykres 15.

Rozkład wyników pomiaru uczuć wstydu
Wykres 16.

Rozkład wyników pomiaru globalnego poczucia winy

Źródło: opracowanie własne. 
Wykres 17. Rozkład wyników pomiaru skruchy

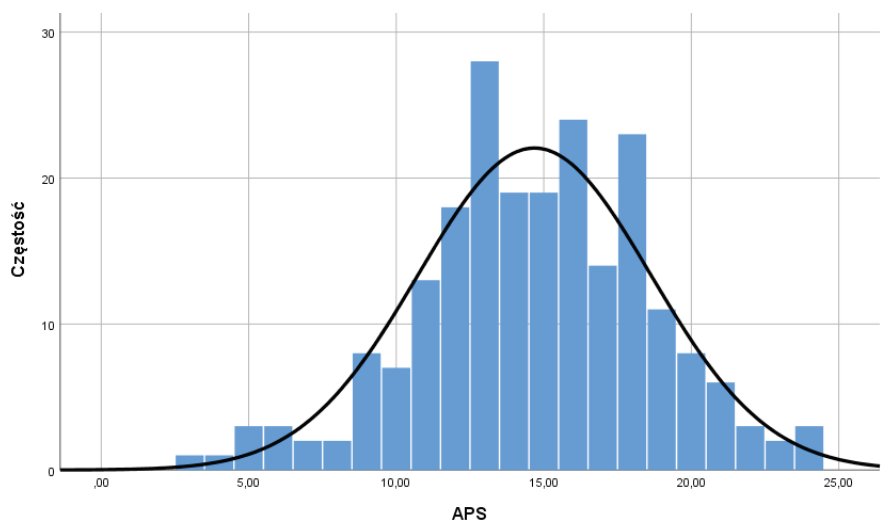

Źródło: opracowanie własne.

Wykres 18. Rozkład wyników pomiaru uczuć negatywnych

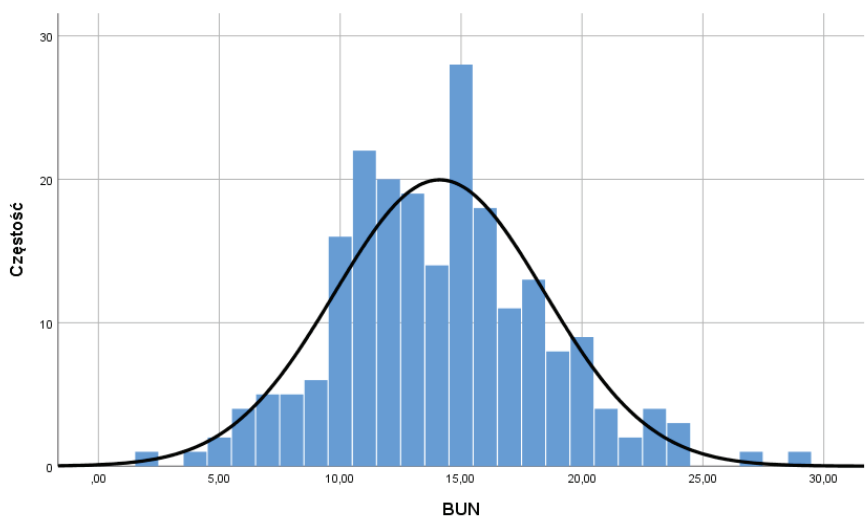

Źródło: opracowanie własne.

Wykres 19.

Rozkład wyników pomiaru nadziei na nagrodę

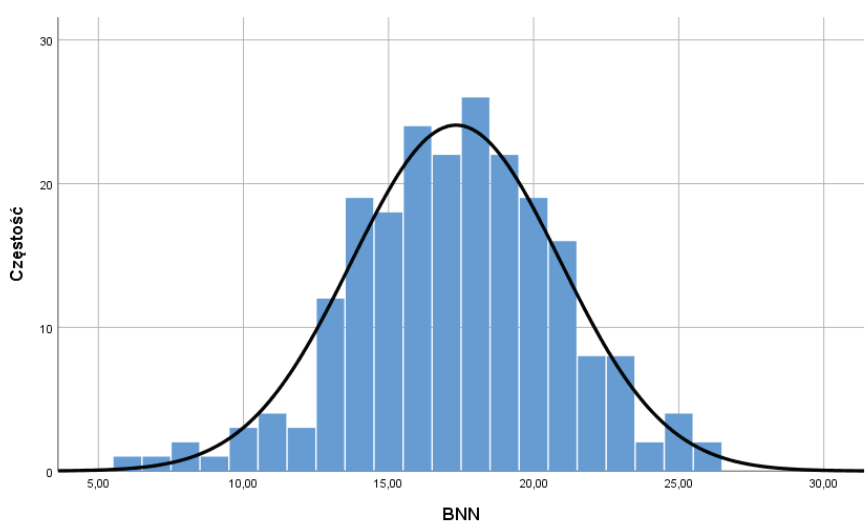

Źródło: opracowanie własne. 


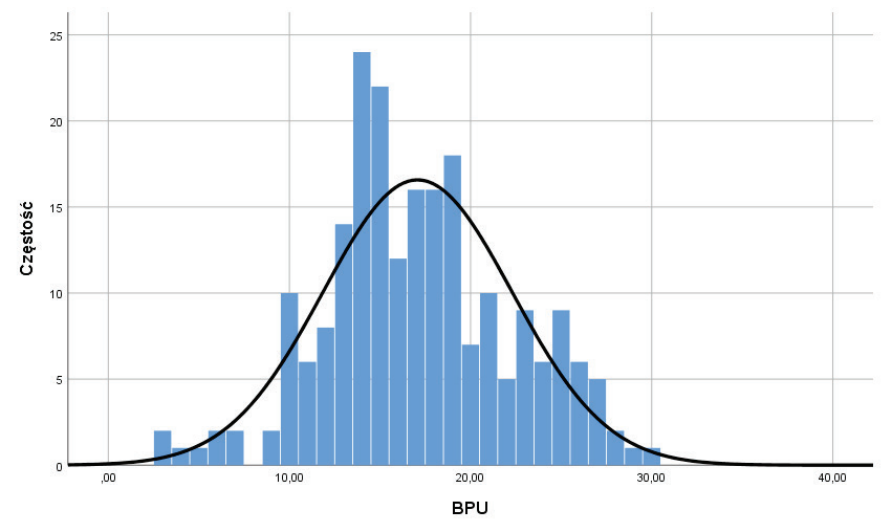

Wykres 20.

Rozkład wyników

pomiaru pychy

Źródło: opracowanie własne.

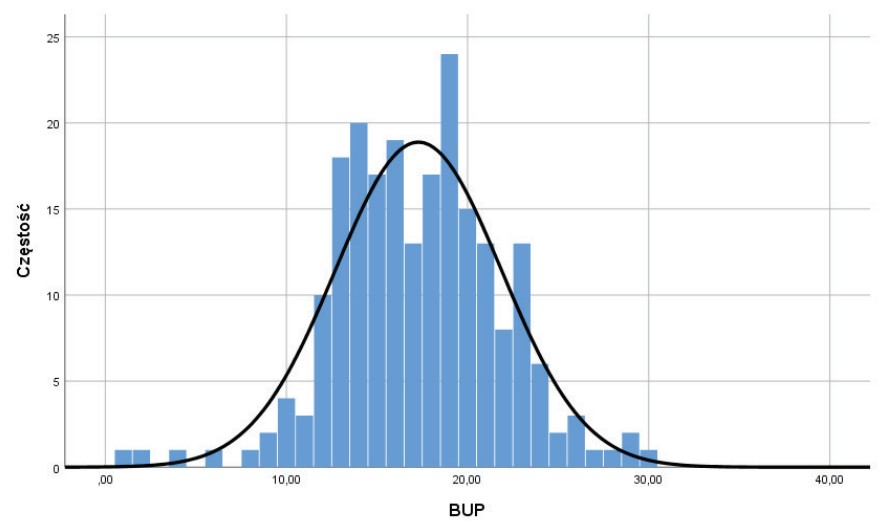

Wykres 21.

Rozkład wyników pomiaru uczuć pozytywnych (umacnianie siebie)

Źródło: opracowanie własne.

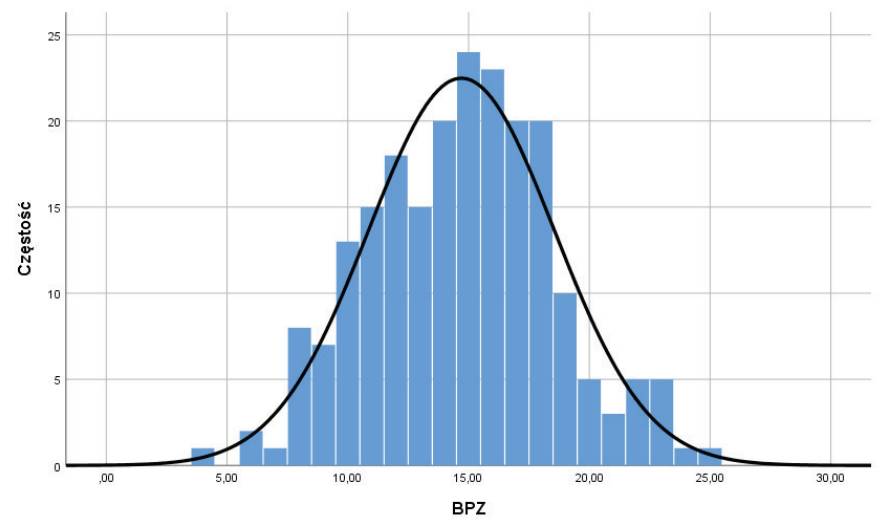

Wykres 22.

Rozkład wyników pomiaru powinności wobec zasad

Źródło: opracowanie własne. 
Objęci badaniem studenci pedagogiki cechowali się zatem największym nasileniem tendencji do przeżywania uczuć związanych z oczekiwaniem dodatkowych wzmocnień zewnętrznych w sytuacjach realizowania norm moralnych, uczuć związanych z globalną, pozytywną ewaluacją ,ja” i poczuciem wyższości wobec innych w takich sytuacjach oraz uczuć pozytywnych związanych z poczuciem siły, spełnienia i zadowoleniem ze swojego osiągnięcia. Ponadto, studentów charakteryzowało obniżone nasilenie uczuć związanych z zaabsorbowaniem negatywną oceną innych w sytuacjach naruszania norm moralnych, tendencji do przeżywania przyjemnych stanów emocjonalnych związanych z gratyfikacją amoralnych motywów oraz obojętności i uczuć wynikających z nieprzyjmowania odpowiedzialności za transgresję moralną na siebie (brak atrybucji wewnętrznej) albo przypisywania jej komuś lub czemuś innemu (atrybucja zewnętrzna).

\section{Zwiq̨zi pomiędzy nastawieniem wobec pracy a wartościami i uczuciami moralnymi}

Analiza korelacji wykazała szereg powiązań pomiędzy badanymi cechami. W tabeli 4 zawarto informacje o zależnościach pomiędzy nastawieniem wobec pracy a wyznawanymi wartościami.

Tabela 4. Wyniki analizy korelacii pomiędzy nastawieniem wobec pracy a wartościami badanych studentów pedagogiki $(\mathrm{N}=222)$

\begin{tabular}{|c|c|c|c|c|c|c|}
\hline \multirow{2}{*}{ Wartości } & \multicolumn{7}{|c|}{ Nastawienie do pracy jako: } \\
\cline { 2 - 7 } & Konieczności & $\begin{array}{c}\text { Powinności } \\
\text { społecznei }\end{array}$ & $\begin{array}{l}\text { Identyfikacji } \\
\text { i tożsamości }\end{array}$ & $\begin{array}{c}\text { Oznaki } \\
\text { prestiżu }\end{array}$ & $\begin{array}{c}\text { Samoreali- } \\
\text { zacii }\end{array}$ & $\begin{array}{c}\text { Kontaktów } \\
\text { społecznych }\end{array}$ \\
\hline Dionizyjskie & $0,544^{* * *}$ & 0,111 & $-0,087$ & $0,387^{* * *}$ & $-0,018$ & $0,162^{*}$ \\
\hline Heraklesowe & $0,373^{* * *}$ & $0,175^{* *}$ & 0,120 & $0,351^{* * *}$ & 0,047 & $0,161^{*}$ \\
\hline Prometejskie & $-0,134^{*}$ & $0,278^{* * *}$ & $0,339^{* * *}$ & $-0,033$ & $0,453^{* * *}$ & $0,299^{* * * *}$ \\
\hline Apollińskie & $-0,075$ & $0,176^{* *}$ & $0,274^{* * *}$ & $-0,070$ & $0,310^{* * *}$ & $0,156^{*}$ \\
\hline Sokratyczne & $-0,087$ & $0,221^{* *}$ & $0,387^{* * *}$ & $-0,103$ & $0,536^{* * *}$ & $0,134^{*}$ \\
\hline
\end{tabular}

${ }^{*} \mathrm{p}<0,05^{* *} \mathrm{p}<0,011^{* * *} \mathrm{p}<0,001$.

Źródło: opracowanie własne. 
Postrzeganie pracy jako ekonomicznej konieczności było umiarkowanie powiązane $\mathrm{z}$ wartościami dionizyjskimi i w nieco słabszym stopniu $z$ heraklesowymi. Oznacza to, że im bardziej studenci nastawieni byli do pracy w ten sposób, tym wyżej wartościowali wygodę życia, materialny dostatek i zabawę, a także dominację nad innymi ludźmi. Postrzeganie pracy jako konieczności wiązało się też z nieco mniejszym nasileniem wartości prometejskich, czyli dotyczących pomocy innym ludziom.

Nastawienie do pracy jako powinności społecznej było słabo powiązane $\mathrm{z}$ nieco większym nasileniem pozytywnych wartości prometejskich, sokratycznych i apollińskich, wyrażających chęć pomocy innym i dążenie do wiedzy i piękna, ale i nieco większe dążenie do dominacji nad innymi, wyrażone wartościami heraklesowymi.

Osoby bardziej dostrzegające $\mathrm{w}$ pracy miejsce realizacji potrzeby identyfikacji i tożsamości osobowej silniej wartościowały dobra sokratyczne, prometejskie i apollińskie, a także wykazywały tendencję do nieco wyższego wartościowania dóbr heraklesowych (rho = 0,120; $p=0,074$ ), podczas gdy nastawienie do pracy jako oznaki prestiżu sprzyjało wyższemu nasileniu wartości dionizyjskich i heraklesowych. Poszukiwanie pracy jako płaszczyzny samorealizacji było umiarkowanie powiązane $z$ wartościami sokratycznymi i prometejskimi, a w stopniu słabym również z apollińskimi. Natomiast nastawienie do pracy jako miejsca nawiązywania kontaktów społecznych było słabo związane $\mathrm{z}$ większym nasileniem wartości prometejskich, ale bardzo słabo wiązało się też z wszystkimi innymi rodzajami wartości, co wskazywać może na zróżnicowaną motywację tych badanych do realizacji swoich potrzeb społecznych w ramach pracy zawodowej.

Analogiczną analizę przeprowadzono zestawiając wyniki pomiaru nastawień wobec pracy z oceną uczuć moralnych studentów, obserwując liczne korelacje o słabych siłach (tabela 5).

Tabela 5. Wyniki analizy korelacii pomiędzy nastawieniem wobec pracy a uczuciami moralnymi badanych studentów pedagogiki $(\mathrm{N}=216)$

\begin{tabular}{|c|c|c|c|c|c|c|}
\hline \multirow{2}{*}{$\begin{array}{c}\text { Uczucia } \\
\text { moralne }\end{array}$} & Konieczności & $\begin{array}{c}\text { Powinności } \\
\text { społecznei }\end{array}$ & $\begin{array}{c}\text { Identyfikacii } \\
\text { i tożsamości }\end{array}$ & $\begin{array}{c}\text { Oznaki } \\
\text { prestiżu }\end{array}$ & Samorealizacii & $\begin{array}{c}\text { Kontaktów } \\
\text { społecznych }\end{array}$ \\
\cline { 2 - 7 } & 0,123 & $0,152^{*}$ & 0,087 & $0,205^{* *}$ & 0,096 & $0,204^{* *}$ \\
\hline AUP & 0,018 & $0,136^{*}$ & 0,075 & 0,115 & 0,108 & $0,157^{*}$ \\
\hline AUE & \multicolumn{7}{|c|}{} & &
\end{tabular}




\begin{tabular}{|c|c|c|c|c|c|c|}
\hline \multirow{2}{*}{$\begin{array}{l}\text { Uczucia } \\
\text { moralne }\end{array}$} & \multicolumn{6}{|c|}{ Nastawienie do pracy jako: } \\
\hline & Konieczności & $\begin{array}{l}\text { Powinności } \\
\text { społecznei }\end{array}$ & $\begin{array}{l}\text { Identyfikacji } \\
\text { i tożsamości }\end{array}$ & $\begin{array}{l}\text { Oznaki } \\
\text { prestiżu }\end{array}$ & Samorealizacji & $\begin{array}{l}\text { Kontaktów } \\
\text { społecznych }\end{array}$ \\
\hline ASK & $0,138^{*}$ & $0,173^{*}$ & $0,181^{* *}$ & $0,166^{*}$ & $0,244^{* * *}$ & $0,267^{* * *}$ \\
\hline AWS & $0,169^{*}$ & 0,111 & 0,121 & $0,227^{* *}$ & 0,110 & 0,129 \\
\hline AGW & $-0,062$ & $0,185^{* *}$ & $0,175^{*}$ & 0,056 & $0,199^{* *}$ & $0,196^{* *}$ \\
\hline APS & $-0,052$ & $0,190^{* *}$ & $0,217^{* *}$ & 0,030 & $0,252^{* * * *}$ & $0,229^{\text {*atak }}$ \\
\hline BUN & $0,302^{* * * *}$ & $0,141^{*}$ & $0,169^{* * *}$ & $0,277^{* * * *}$ & $0,189^{* *}$ & $0,190^{* * *}$ \\
\hline BNN & $0,139^{*}$ & $0,186^{* *}$ & $0,179^{* *}$ & $0,153^{*}$ & $0,287^{* * * *}$ & $0,216^{* *}$ \\
\hline BPY & 0,011 & $0,183^{* *}$ & $0,156^{*}$ & 0,059 & $0,212^{* *}$ & $0,165^{*}$ \\
\hline BUP & 0,063 & $0,187^{* *}$ & $0,232^{* *}$ & 0,131 & $0,262^{* * * *}$ & $0,265^{* * * *}$ \\
\hline BPZ & 0,120 & $0,231^{* *}$ & $0,242^{* * * *}$ & $0,180^{* *}$ & $0,202^{* *}$ & $0,210^{* *}$ \\
\hline
\end{tabular}

A - przekraczanie norm, B - realizowanie norm, AUP - uczucia pozyływne, AUE - uczucia eksternalizacyine i dystansowanie się od odpowiedzialności, ASK - strach przed karq, AWS - wstyd, AGW - globalne poczucie winy, APS - poczucie skruchy, BUN - uczucia negatywne, $B N N$ - nadzieja na nagrodę, $B P Y$ - pycha, $B U P$ uczucia pozyływne (umacnianie siebie), $B P Z$ - powinność wobec zasad. ${ }^{*} p<0,05{ }^{* *} p<0,01{ }^{* * *} p<0,001$.

Źródło: opracowanie własne.

Nastawienie do pracy jako konieczności było słabo powiązane z uczuciami negatywnymi w sytuacji przestrzegania norm, zaś bardzo słabo z takimi uczuciami, jak wstyd, strach przed karą, nadzieja na nagrodę. Osoby nastawione do pracy w ten sposób wykazywały również nie w pełni istotną tendencję do odczuwania uczuć pozytywnych w sytuacji łamania norm (rho $=0,123 ; \mathrm{p}=0,071)$ oraz powinności wobec zasad ( $\mathrm{rho}=0,120 ; \mathrm{p}=0,080$ ).

Osoby bardziej postrzegające pracę jako społeczną powinność cechowały się nieco wyższym odczuwaniem wszystkich uczuć, poza wstydem. Dążenie do identyfikacji i potwierdzenia tożsamości w pracy sprzyjało nieco większemu odczuwaniu powinności wobec zasad, umacniania siebie, poczucia skruchy, strachu przed karą, nadziei na nagrodę, poczucia winy, pychy oraz uczuć negatywnych w sytuacji przestrzegania norm. Ponadto wykazywały nie w pełni istotną tendencję do większego odczuwania wstydu (rho =0,121; $\mathrm{p}=0,076$ ).

Studenci szukający w pracy oznak prestiżu wykazywali zarówno więcej uczuć negatywnych w kontekście realizacji norm oraz więcej 
pozytywnych w odniesieniu do ich przekraczania, a przy tym więcej wstydu, powinności wobec zasad, strachu przed karą i nadziei na nagrodę.

Poszukiwanie w pracy możliwości samorealizacji współwystępowało z większym odczuwaniem wszystkich uczuć związanych z realizacją norm moralnych, a w kontekście ich przekraczania - z wyższym strachem przed karą, globalnym poczuciem winy oraz poczuciem skruchy. Również nastawienie do pracy jako realizacji potrzeby kontaktów społecznych powiązane było $\mathrm{z}$ wszystkimi uczuciami związanymi $\mathrm{z}$ realizacją norm, także $\mathrm{z}$ większą skruchą, strachem przed karą, poczuciem winy, uczuciami pozytywnymi w sytuacjach przekraczania norm, a przy tym nieznacznie większą siłą odczuć eksternalizacyjnych i tendencją do odczuwania wstydu (rho $=0,129 ; \mathrm{p}=0,058)$.

Wyniki wskazują, że najkorzystniejszymi wartościami i uczuciami moralnymi cechowały się osoby, które w większym stopniu postrzegały pracę jako narzędzie samorealizacji. Pozytywny obraz badanych zmiennych wykazywały też osoby nastawione do pracy jak do powinności społecznej, miejsca realizacji potrzeb tożsamości i identyfikacji oraz nawiązywania kontaktów społecznych. Natomiast traktowanie pracy jako ekonomicznej konieczności czy oznaki społecznego prestiżu powiązane było z mniej moralnym nastawieniem do realizacji i przekraczania norm oraz większym nasileniem niekonstruktywnych potrzeb doznawania uciech doczesnych i dominacji nad innymi ludźmi.

\section{Zakończenie}

Według pedagoga Henryka Nogi osobowość może być pojmowana jako ciągłe tworzenie ładu moralnego w sobie oraz w otaczającej człowieka rzeczywistości ${ }^{37}$. Istotnym elementem tworzenia ładu moralnego jest wybór i wierność wartościom, decydującym o nastawieniu wobec życia, w tym wobec pracy. Aksjologiczny wymiar pracy jest szczególnie istotny w tych zawodach, które sprawowane są w relacji z drugim człowiekiem i w poczuciu odpowiedzialności za niego.

37 H. Noga, Aksjologiczno-spoteczne przejawy postmodernizmu w treściach medialnych i multimedialnych jako wyzwanie dla edukacji, w: Problemy wspótczesnej pedagogiki - teoria i praktyka, red. H. Noga, P. Piotrowski, Nowy Sącz 2011, s. 9. 
Do takich należy zawód nauczyciela-wychowawcy, w którym troska o kształtowanie osobowości ucznia-wychowanka powinna współwystępować z nieustannym staraniem o własny ład moralny. Przeprowadzone badania potwierdziły korelację pomiędzy wartościami i uczuciami przeżywanymi w sytuacjach moralnych $\mathrm{z}$ nastawieniem wobec pracy.

Spośród badanych typów nastawień wobec pracy badani studenci pedagogiki cechowali się największym nasileniem postrzegania pracy jako możliwości samorealizacji.Jest to wynik wskazujący na orientację podmiotową, podkreślającą rolę człowieka jako sprawcy i podmiotu pracy. Ten humanistyczny komponent jest szczególnie istotny w zawodzie nauczyciela-wychowawcy, sprawowanym w relacji z drugim człowiekiem i ukierunkowanym na dobro indywidualne i społeczne. Podmiotowe zorientowanie oznacza podporządkowanie pracy dobru człowieka. Znajdowanie w pracy wartości realizowania swoich możliwości i zainteresowań ma pozytywne konsekwencje dla obu stron relacji dydaktyczno-wychowawczej. Nauczyciel-wychowawca, który poprzez pracę spełnia swoje życiowe powołanie, odkrywa w sobie i kształtuje osobową wartość istotną dla innych ${ }^{38}$. Następuje wzajemne warunkowanie: osoba, która dzięki pracy rozwija swoje możliwości i realizuje zamierzenia jest zadowolona i umotywowana, by jeszcze lepiej wykonywać pracę, a „wkładając w nią serce i rozum” podwyższa jakość jej wykonania, poziom swojego rozwoju i zadowolenia. Pasja i profesjonalizm rodzą poczucie zadowolenia zawodowego, ale też umożliwiają realizację planów pozazawodowych, łącząc w ten sposób zadowolenie zawodowe z poczuciem szczęśliwości życiowej. Być może taki stan miał na myśli chiński filozof i myśliciel Konfucjusz, stwierdzając: „Wybierz sobie zawód, który lubisz, a całe życie nie będziesz musiał pracować” ${ }^{39}$. Osoba, dla której praca jest drogą i terenem samorealizacji, jest $\mathrm{w}$ niej radośnie utrudzona, postrzega trudy jako wyzwania, a ich pokonywanie jako zdobywanie nowych doświadczeń. Co ważne, zadowolenie $\mathrm{z}$ wykonywanej pracy nastawia pozytywnie do tych, wobec których jest sprawowana. Uczeń-wychowanek i jego rodzice spotykają się z nauczycielem-wychowawcą,

I. Jazukiewicz, Pedeutologiczna teoria cnoty, dz. cyt., s. 145.

39

Cyt. za: S.L. Popek, O istocie i mechanizmach pasji, w: O pasjach cudzych i wtasnych-profesorowie, red. M. Dudzikowa i M. Nowak, Lublin 2015, s. 16. 
który jest kompetentny i życzliwy. Mają realny przykład osoby urzeczywistniającej swoje rozwojowe możliwości i realizującej życiowe zamierzenia. Mogą korzystać z jej profesjonalizmu w wymiarze poznawczym i działaniowym.

Dominujący wśród badanych swoim nasileniem typ nastawienia wobec pracy jako samorealizacji ma również możliwe zagrożenia w rozwoju i profesjonalizmie przyszłych pedagogów, a w konsekwencji także w relacji z uczniem-wychowankiem. Nastawienie w pracy pedagogicznej na własny rozwój może bowiem generować preferencję własnego rozwoju ponad rozwój ucznia-wychowanka. Tymczasem specyfika pracy pedagogicznej i bycie nauczycielem-wychowawcą zakładają świadomość obecności i pierwszeństwo pojawienia się drugiej osoby: obecność ucznia-wychowanka nadaje sens i potrzebę byciu pedagoga. We wzajemnej relacji obie strony urzeczywistniają swoje potencjalne możliwości rozwojowe, ale sytuacja dydaktyczno-wychowawcza wymaga priorytetu osiągnięcia optimów rozwojowych wychowanka ${ }^{40}$. Ponadto, nastawienie na samorealizację może powodować stawianie własnej osoby w centrum starań i działań zawodowych, współwystępować z poczuciem wyższości i rozwojem form egocentryzmu i egoizmu, co przeczy istocie zawodu nauczyciela-wychowawcy. Istotą jest ukierunkowanie nauczyciela-wychowawcy na osobę ucznia-wychowanka oraz uczynienie jego rozwoju priorytetem zawodowych działan ${ }^{41}$. Własny rozwój jest konieczny, by podołać temu wyzwaniu. Nie jest więc celem samym w sobie, lecz ma swój cel: jest nim usprawnienie w tworzeniu warunków sprzyjających rozwojowi ucznia-wychowanka. Jego rozwój jako moralne dobro jest przedmiotem profesjonalnej troski pedagoga. To zatroskanie wymaga usprawnienia nie tylko poznawczego i działaniowego, lecz także moralnego. To właśnie wymiar etyczny profesjonalizmu decyduje między innymi o tym, jakie oblicze i przeznaczenie ma samorealizacja nauczyciela-wychowawcy. Skoro jednak badani studenci pedagogiki cechowali się raczej wysokim wartościowaniem wiedzy i poznania oraz pomocy innym ludziom i raczej obniżonym dążeniem do dominacji i posiadania władzy nad innymi ludźmi, a w pomiarze uczuć moralnych dominowały pozytywne wartości związane $\mathrm{z}$ realizowaniem norm (choć uwagę zatrzymuje nasilenie

40 Por. I. Jazukiewicz, Pedeutologiczna teoria cnoty, dz. cyt., s. 139-140.

41 Por. tamże, s. 152. 
pychy), to można przypuszczać pożądane rozumienie nastawienia na samorealizację w ich przyszłym zawodzie. Tym bardziej, że badanie potwierdziło korelację tych czynników. Można więc wnioskować o najwyższym nasileniu tego typu nastawienia wobec pracy wśród badanych studentów, które najbardziej adekwatnie odpowiada specyfice zawodu nauczyciela-wychowawcy. Współwystępuje on ze szczególnie pożądaną hierarchią wartości sokratycznych i prometejskich oraz pożądaną dominacją nasilenia uczuć pozytywnych w sytuacji przestrzegania norm moralnych.

Analogiczne badanie zostało wcześniej przeprowadzone wśród studentów medycyny ${ }^{42}$. Przyszli lekarze, tak samo jak przyszli pedagodzy, cechowali się dominującym nasileniem nastawienia wobec pracy jako sposobu samorealizacji i najmniej nasilonym patrzeniem na pracę jako konieczność wynikającą z presji ekonomicznej oraz oznakę prestiżu społecznego. Wśród wartości również dominowały sokratyczne, a heraklesowe, związane $\mathrm{z}$ dążeniem do dominacji nad innymi, miały najmniejsze nasilenie. Studenci pedagogiki jednak wyżej wartościowali altruizm i poświęcenie (wartości prometejskie), a mniej komfort i wygodę (wartości dionizyjskie). Wspólną cechą jest dominacja nasilenia uczuć pozytywnych w sytuacji realizowania norm moralnych. Wspomniane badania potwierdziły także korelację między zmiennymi ${ }^{43}$. Podobieństwo wyników w obu grupach badawczych jest analogiczne do podobieństwa specyfiki zawodu lekarza i pedagoga: wymagają one od wykonawcy ukierunkowania na dobro drugiej osoby w poczuciu odpowiedzialności za jej życie i rozwój. Jest to powodem wysokich standardów poznawczych, działaniowych i etycznych w każdym z nich. Stąd uzasadnione jest jednolite pięcioletnie kształcenie lekarzy, natomiast mniej zrozumiałe dopuszczenie do pracy pedagogów bez przygotowania magisterskiego.

Stan chaosu aksjonormatywnego przetrwa tylko to, co jest prawdziwe. Nie wystarcza bowiem do jego pokonania wolność. To

42 A. Jazukiewicz, A. Starkowska, D. Suchecka, Moralne korelaty nastawień wobec pracy studentów medycyny, w: Sprawności moralne a wartości, red. I. Jazukiewicz, E. Rojewska, Szczecin 2017. W badaniu wykorzystano inną listę nastawień wobec pracy oraz inną listę wartości, chociaż zachowano tę samą typologię obu zmiennych.

43 A. Jazukiewicz, A. Starkowska, D. Suchecka, Moralne korelaty nastawień wobec pracy studentów medycyny, dz. cyt., s. 172-174. 
przecież człowiek wolny planuje wojnę, chociaż ma doświadczenie jej skutków; w imię wolności odbiera życie drugiemu, chociaż chroni własne; w wolności głosi to, co jest fałszywe. Ci, którzy widzą p r a wdziwie, są zobowiązani i odpowiedzialni za uporządkowanie aksjonormatywnego ładu społeczno-moralnego. Takie zaangażowanie aksjologiczne jest oczekiwane przede wszystkim od nauczycieli-wychowawców, którzy troszczą się nie tylko o własne wzrastanie w mądrości, lecz wspóluczestniczą w rozwoju innych osób - zwłaszcza od profesjonalnych nauczycieli-wychowawców.

\section{Bibliografia}

Beier W., Pozytywne myślenie, przeł. M. Skalska, Bellona, Warszawa 1997.

Bżaława I.T., Nastawienie - podstawa regulacji psychicznej, PWN, Warszawa 1970.

Csíkszentmihályi M., Przeptyw. Psychologia optymalnego doświadczenia, przeł. M. Wajda-Kacmajor, Moderator, Taszów 2005.

Czapiński J., Osobowość szczęśliwego cztowieka, „Charaktery” 2004, nr 9, s. $25-26$.

Fromm E., Mieć czy byci?, przeł. J. Karłowski, Rebis, Poznań 2003.

Furmanek W., Humanistyczna pedagogika pracy. Praca a jakość życia cztowieka, Wydawnictwo Uniwersytetu Rzeszowskiego, Rzeszów 2016.

Furmanek W., Rozumienie wartości pracy a orientacje życiowe cztowieka, „Pedagogika Pracy" 2004, nr 45, s. 59-67.

Furmanek W., Zarys humanistycznej teorii pracy, Wydawnictwo Adam Marszałek, Torun 2008.

Jan Paweł II, Laborem Exercens, w: Encykliki Ojca Świętego Jana Pawta II, Znak, Kraków 1997, s. 141-213.

Jazukiewicz A., Starkowska A., Suchecka D., Moralne korelaty nastawień wobec pracy studentów medycyny, w: Sprawności moralne a wartości, red. I. Jazukiewicz, E. Rojewska, Wydawnictwo Naukowe Uniwersytetu Szczecińskiego, Szczecin 2017, s. 161-185.

Jazukiewicz I., Pasja jako istotny wymiar doświadczania pracy, „Studia Paedagogica Ignatiana" 2017, nr 2, s. 85-101.

Jazukiewicz I., Pedeutologiczna teoria cnoty, Wydawnictwo Naukowe Uniwersytetu Szczecińskiego, Szczecin 2012.

Kozielecki J., Koncepcje psychologiczne cztowieka, Wydawnictwo Akademickie „Żak”, Warszawa 1995.

Legowicz J., O Nauczycielu mistrzu samego siebie, w: Pedeutologia. Badania $i$ koncepcje metodologiczne, red. A. Kotusiewicz, H. Kwiatkowska, W. Zaczyński, Wydawnictwo Uniwersytetu Warszawskiego, Warszawa 1993, s. $15-25$. 
Łukasik J.M., Doświadczanie życia codziennego. Narracje nauczycielek na przetomie życia, Oficyna Wydawnicza „Impuls”, Kraków 2013.

Noga H., Aksjologiczno-spoteczne przejawy postmodernizmu w treściach medialnych i multimedialnych jako wyzwanie dla edukacji, w: Problemy wspótczesnej pedagogiki - teoria i praktyka, red. H. Noga, P. Piotrowski, PWSZ, Nowy Sącz 2011, s. 8-18.

Okoń W., Stownik pedagogiczny, PWN, Warszawa 1975.

Popek S.L., O istocie i mechanizmach pasji, w: O pasjach cudzych $i$ wtasnych profesorowie, red. M. Dudzikowa i M. Nowak, Wydawnictwo KUL, Lublin 2015, s. 15-35.

Popper K., W poszukiwaniu lepszego świata, przeł. A. Malinowski, Książka i Wiedza, Warszawa 1997.

Strus W., Dojrzatośc emocjonalna a funkcjonowanie moralne, Wydawnictwo Liberi Libri, Stare Kościeliska 2012.

Strus W., Skala Uczuć Moralnych (SUM): konstrukcja i wtaściwości psychometryczne, „Studia Psychologica” 2010, nr 10, s. 273-313.

Strus W., Żylicz P.O., Emocje samoświadomościowe - podstawowe rozróżnienia i narzędzia pomiaru, w: Metody badania emocji i motywacji, red. H. Gasiul, Difin, Warszawa 2018, s. 80-109.

Suchodolski B., Skąd i dokąd idziemy, „Muza”, Warszawa 1999.

Tischner J., Myślenie wedtug wartości, Znak, Kraków 1993.

Walkiewicz J., Petna moc możliwości, Helion, Gliwice 2015.

Wilkins R., Pozytywne myślenie... i co dalej, przeł. E. Jurewicz, Medium, Warszawa 1997.

Wojtyła K. [Jan Paweł II], „Jestem bardzo w rękach Bożych”. Notatki osobiste 1962-2003, Znak, Kraków 2014.

\section{ADRES DO KORESPONDENCJ:}

Dr hab. Iwona Jazukiewicz, prof. US

Uniwersytet Szczeciński

Wydział Teologiczny

e-mail: iwona.jazukiewicz@usz.edu.pl 